\title{
Lutas simbólicas na arena midiática: o poder de agência do Ministério Público e as controvérsias sobre a PEC 37
}

Cláudia Regina Fonseca Lemos

Antonio Teixeira de Barros

\section{Introdução}

Em 2013, pressionados pelas manifestações públicas que se espalharam pelo país no mês de junho, os deputados federais rejeitaram a proposta de emenda à Constituição (PEC) que tornava a investigação criminal prerrogativa exclusiva das polícias, proibindo o Ministério Público (MP) de apurar crimes diretamente, sem participação policial. Antes dos eventos de junho, a PEC 37, apelidada pelo MP de "PEC da impunidade", tinha sua aprovação dada como certa. Entretanto, ao ser posta em votação pelo Plenário da Câmara dos Deputados, no dia 26 daquele mês, depois de ser incluída nos cartazes dos manifestantes, foi rejeitada por 430 dos 513 deputados.

Este artigo apresenta resultado de pesquisa que verificou como o Ministério Público foi bem-sucedido em promover o enquadramento do debate junto à imprensa e à opinião pública, vinculando a PEC ao incentivo à impunidade, especialmente nos casos de corrupção. O objetivo é analisar as lutas simbólicas na arena midiática acerca das controvérsias relacionadas à PEC 37. Isso requer compreender como os diversos atores interessados no assunto travaram o debate, levando o tema a chegar às manifestações de junho de 2013, além de examinar como o MP conseguiu agenciar as mídias a seu favor, uma vez que os argumentos do MP passaram a ser sistematicamente reproduzidos pela imprensa, com amplo espaço de voz para aumentar o poder de palavra dos representantes do MP. Os argumentos a favor da PEC foram associados pela imprensa à continuidade da corrupção política e à falta de isenção e lisura nas investigações policiais, devido à autonomia limitada das polícias civil e militar.

A perspectiva teórica das lutas simbólicas (Bourdieu, 1989) justifica-se no exame do caso porque ocorreu uma nítida batalha no campo simbólico, o qual compreende imagens, discursos e representações acionadas pelos atores com o intuito de fazer prevalecer suas respectivas opiniões e juízos a respeito do tema. Para o autor, os sistemas simbólicos, enquanto instrumentos estruturados e estruturantes de comunicação e conhecimento, cumprem uma função política de imposição e de legitimação da dominação de um grupo sobre os demais. O campo de produção simbólica é, portanto, um campo de 
lutas simbólicas. Em outras palavras, os sistemas simbólicos produzidos por um corpo de promotores e procuradores entram em disputa pela legitimação perante um grupo de delegados de polícia, seus representantes no parlamento e outros parlamentares com interesses próximos, como se observa no caso das controvérsias em torno da PEC 37.

Interessa, portanto, examinar, numa situação concreta de discussão de uma proposição legislativa, os artifícios retóricos e estratégicos utilizados para articular o debate em arenas discursivas diversas e inter-relacionadas, mobilizando diferentes atores como a imprensa, parlamento, instituições de governo, área jurídica e organizações da sociedade civil, até chegar às manifestações de junho de 2013 e à votação na Câmara dos Deputados.

Para compreender como se operam essas lutas simbólicas, a pesquisa que deu origem a este artigo teve como base material jornalístico, além de questionário e entrevistas com representantes do MP. O corpus do material publicado pela imprensa sobre a PEC 37 compreende um conjunto de 351 textos referentes ao período de janeiro de 2012 a junho de 2013, em três jornais e quatro revistas de circulação nacional: O Globo, Folha de S. Paulo, O Estado de S. Paulo, Veja, Época, IstoÉ e Carta Capital. Os textos foram classificados de acordo com o gênero jornalístico e quanto à explicitação ou não de posição em relação à PEC. As fontes citadas foram classificadas de acordo com a posição, além da instituição de origem. Buscou-se identificar os pontos de vista que obtiveram publicidade nos principais veículos impressos de comunicação no Brasil. A análise concentrou-se nos impressos por seu papel de referência (Wolf, 1995).

Como será demonstrado mais adiante, essa análise indicou o claro predomínio da posição contrária à PEC 37, defendida pelo Ministério Público. A partir daí o levantamento documental se concentrou na mobilização do MP contra a PEC. Foi também aplicado um questionário sobre a participação institucional na campanha. O questionário foi respondido por representantes de 24 dos 30 órgãos do MP nos estados e da União, além do Conselho Nacional do Ministério Público e das principais associações de membros do MP. Complementarmente, foram entrevistados os presidentes e assessores de comunicação dessas associações.

As entrevistas foram realizadas no segundo semestre de 2014 , em uma perspectiva qualitativa, pautada pelo princípio sociológico de pesquisa compreensivista, mais especificamente apoiado no pressuposto metodológico de Giddens (2003) de que existe um processo de dupla hermenêutica nesse tipo de pesquisa. Isso significa que o conhecimento sociopolítico deve passar primeiro pela análise da percepção dos próprios agentes envolvidos, no caso, os dirigentes e assessores do MP e de associações que foram entrevistados. Em segunda instância é que passa pelo olhar dos pesquisadores. Esse foi o princípio metodológico que orientou a pesquisa no que se refere às entrevistas e questionários. 


\section{As controvérsias sobre o poder de investigar}

Um dos elementos basilares das causas públicas são as controvérsias, consideradas aspectos fundamentais da análise sociológica, uma vez que revelam lógicas de ação e estratégias dos atores (Boltanski e Thévenot, 1991). Em perspectiva analítica similar, Giumbelli (2002, p. 95) complementa que as controvérsias mobilizam uma variedade de agentes sociais, mesmo quando se circunscrevem a questões específicas. Trata-se de "um momento de expressão e redefinição de pontos e problemas, os quais permanecem importantes, às vezes até cruciais, na constituição de uma sociedade, mesmo quando não despertam interesse generalizado ou intenso".

Desse modo, o debate público gerado a partir de tais polêmicas torna-se uma expressão da discursividade pública, "essencial para entender os traços constitutivos da sociedade de que fazem parte as personagens da controvérsia". Afinal, "a controvérsia é uma espécie de drama social, que revela, mas também reconfigura definições de realidade, explicitando o conflito que existe em torno dessas definições" (Giumbelli, 2002, p. 95-97). Os dramas sociais são considerados momentos em que as sociedades discutem a si mesmas, a partir de narrativas sobre si e para si, como reiteram Durão e Coelho (2014).

Trata-se, portanto, do exame empírico de "conflitos de argumentação" e seus modos de generalização, a fim de inseri-los na esfera pública. As tentativas de generalização (dessingularização) constituem, na realidade, uma estratégia de validação dos argumentos arregimentados pelos atores em disputa, com o objetivo de tornar gerais objetivos inicialmente pertencentes apenas a um segmento, mediante o investimento discursivo pautado em provas de grandeza. Isso implica a construção de um pacote argumentativo que tem como substrato uma ordem calcada nos princípios de equivalência típicos do regime de ação motivado pela justiça (Boltanski, 2000). Tais provas remetem à grandeza cívica como princípio garantidor da generalização da denúncia, além de requisito para que a causa seja socialmente percebida e reconhecida como legítima e justa. Em suma, trata-se de um amplo investimento discursivo dos atores, com o propósito de arregimentar aliados e enfraquecer ou desqualificar os argumentos de seus opositores.

A própria noção de denúncia pública evoca princípios éticos e morais que são constituintes da ordem e da estrutura das sociedades, tais como bem comum, justiça, igualdade jurídica, dignidade, entre outros termos. A denúncia é articulada pela indignação moral, associada à exigência de justiça e expectativa de punição dos atores considerados agentes da situação crítica causadora da quebra do contrato social de direitos (Boltanski e Thévenot, 1991; Lança, 2006). O ato de denunciar, portanto, constitui o gesto fundador da tentativa de transformar um fato particular em causa pública, o que os autores citados denominam de dessingularização. Essa foi a principal estratégia do Ministério Público no caso da articulação contrária à aprovação da PEC 37 pela Câmara dos Deputados. 
O Ministério Público brasileiro ganhou contornos que conhecemos hoje com a Constituição de 1988. A partir daí, e com a aprovação posterior de uma série de leis ${ }^{1}$, a instituição tornou-se independente do Poder Executivo e teve suas atribuições ampliadas para assumir o papel de "defensor da sociedade". Além das atribuições históricas de acusar autores de crimes em nome do Estado, de fiscalizar a aplicação da lei para resguardar direitos individuais indisponíveis e de defender incapazes, passou a defender direitos coletivos, o que levou promotores de Justiça e procuradores da República a adquirir significativa relevância política.

Arantes (2000, p. 3-10) defende que a ampliação de atribuições foi resultado da iniciativa deliberada e bem-sucedida dos próprios integrantes do Ministério Público, movidos pelo que vasta bibliografia da área do direito define como "ativismo judicial" e que o autor prefere caracterizar como "voluntarismo político". Durante as décadas de 1980 e 1990, o ativismo teria se tornado a visão dominante no Ministério Público - se não em termos numéricos, certamente em termos políticos - e teria obtido uma sucessão de vitórias legislativas no sentido de fortalecer a instituição. Barenboïm sintetiza o resultado dessa atuação:

Em todo caso, o Ministério Público conta hoje com um aparato corporativo e material destinado a compelir o Estado a implementar políticas públicas, de modo a possibilitar o pleno exercício da cidadania por toda a população. Compete a tal instituição, fiscalizar o processo de universalização do serviço público, para assim suplantar o déficit democrático que até então condicionou as políticas nesse setor (Baremboïm, 2014).

A partir do final da década de 1990, o Ministério Público, empoderado e visto pela sociedade como uma espécie de novo quarto poder, passa a sofrer ataques no campo legislativo. Começam a ser apresentadas propostas que buscam limitar suas prerrogativas, e que são defendidas por grupos de interesses conflitantes com a atuação da instituição sejam eles autoridades atingidas por investigações ou corporações disputando espaços de atuação. No primeiro caso está a chamada Lei da Mordaça, como ficou conhecido o Projeto de Lei 2.961, apresentado em 1997 pelo Poder Executivo para considerar abuso de autoridade a divulgação de informações sobre processos em andamento, e que chegou a ser aprovado na Câmara em 1999, para ser arquivado no Senado em 2007. No segundo caso está a PEC 37, proposta em 2011 pelo deputado Lourival Mendes, delegado de polícia eleito pelo PTdoB do Maranhão, aprovada em Comissão Especial em dezembro de 2012 e arquivada pelo Plenário da Câmara dos Deputados em junho de 2013.

\footnotetext{
${ }^{1}$ Destacam-se a Lei Orgânica do Ministério Público (Lei 8625/1993) e a Lei Orgânica do Ministério Público da União (Lei Complementar 75/1993). Antes disso, o Código de Processo Civil de 1973, introdutor do conceito de defesa do interesse público, e a Lei da Ação Civil Pública (Lei 7347/1985) já iniciavam a ampliação dos instrumentos disponíveis para atuação do Ministério Público (Arantes, 2000, p. 9).
} 
A controvérsia sobre o poder de investigar do Ministério Público começou dez anos antes $^{2}$. Inicialmente, a tese de que havia previsão constitucional para o MP obter provas diretamente foi defendida por advogados em processos movidos pelo MP contra acusados por crimes relacionados a corrupção e também em outros casos. Para o Ministério Público, tratava-se apenas de um artifício de defesa, sem qualquer base, pois aos integrantes da instituição parecia absurdo que o encarregado de oferecer a denúncia não pudesse obter provas. "Quem pode mais, pode menos", diziam. Contudo, recursos baseados nessa tese chegaram ao Supremo Tribunal Federal, estando pendentes de decisão quando da apresentação da PEC $37^{3}$. Delegados, com prestígio crescente depois de operações policiais de impacto, viram aí uma oportunidade de fortalecer a posição da categoria no sistema de Justiça.

Aqui, observa-se que os delegados usam como estratégia de suas lutas simbólicas o capital da credibilidade do trabalho de investigação por eles realizado, uma tentativa de afirmar o poder do conhecimento perito. Embora as lutas simbólicas operem com sistemas de valores, os delegados usam como tática o discurso do poder da técnica, a fim de dificultar a refutação dos argumentos e esmaecer o tom político das disputas. Trata-se de uma forma de conferir legitimidade às suas justificações, acionando a técnica e o conhecimento perito como provas argumentativas para justificar suas posições (Boltanski e Thévenot, 1991).

A PEC era um texto de 12 linhas que acrescentava novo parágrafo ao artigo 144 da Constituição, para tornar a apuração de infrações penais uma atribuição privativa, ou seja, exclusiva, das polícias federal e civil. Na falta desse tipo de proibição, a investigação em casos criminais era feita até então principalmente pelas polícias, mas também diretamente pelo Ministério Público, que se valia ainda, em processos criminais, de dados colhidos em investigações conduzidas por instituições como a Receita Federal, o Banco Central, a Controladoria Geral da União, o Tribunal de Contas da União e mesmo pelas Comissões Parlamentares de Inquérito. Com a aprovação da proposta, tudo isso deixaria de ser possível.

O autor da proposta, o então deputado Lourival Mendes (PTdoB-MA), na justificativa explicou que "o inquérito policial é o único instrumento de investigação criminal que, além de sofrer o ordinário controle pelo juiz e pelo promotor, tem prazo certo, fator importante para a segurança das relações jurídicas ${ }^{\prime 4}$. Como se observa no trecho citado, o autor da

\footnotetext{
${ }^{2}$ Entrevista do secretário especial do Gabinete do Procurador-Geral da República, procurador regional da República Danilo Pinheiro Dias, concedida à autora em 12 nov. 2014.

${ }^{3} \mathrm{Em}$ várias ocasiões, ministros e turmas do STF haviam decidido favoravelmente ao poder de investigar do MP. Mas apenas em 14 maio 2015, quase dois anos depois da derrubada da PEC 37, o Plenário do STF decidiu a questão em favor do MP.

Disponível em: <http://www.stf.jus.br/portal/cms/verNoticiaDetalhe.asp?idConteudo=291563>. Acesso em: 11 nov. 2015.

${ }^{4} \mathrm{O}$ texto e a justificativa completa estão disponíveis em:

<http://www.camara.gov.br/proposicoesWeb/prop_mostrarintegra;jsessionid=AE5768E918218D6F691E3D85 A52B5047. proposicoesWeb2?codteor=969478\&filename $=P E C+37 / 2011>$. Acesso em: 14 maio 15.
} 
PEC apela para o argumento da segurança jurídica, uma razão alegada de forma recorrente nos debates jurídicos e de fácil aceitação pela opinião pública. Percebe-se que o autor da PEC, como ator das lutas simbólicas, usa as mesmas estratégias argumentativas adotadas por sua categoria, a dos delegados de polícia. A justificação é construída com base em alegações técnicas, embora as lutas simbólicas em torno do tema sejam efetivamente políticas.

Apresentada na Câmara dos Deputados em junho de 2011, a PEC teve parecer pela admissibilidade aprovado em dezembro do mesmo ano pela Comissão de Constituição e Justiça. A comissão especial formada para apreciar a proposta, em abril de 2012, tinha composição claramente desfavorável ao Ministério Público. Depois de diversas audiências públicas, com a maioria dos argumentos e setores representados se posicionando contrariamente à PEC, a comissão aprovou em dezembro de 2012 um relatório do deputado Fábio Trad, do PMDB de Mato Grosso do Sul, que alterava substancialmente a proposta original, incluindo três hipóteses em que seria permitido ao Ministério Público investigar: nos casos de crimes previstos por agentes públicos ou envolvendo organizações criminosas; nos casos em que inquéritos civis conduzidos pelo MP tivessem desdobramentos criminais (mesmo assim o inquérito policial deveria ser instaurado); e para complementar provas obtidas por órgão não policiais, com atribuição investigatória constitucional, como as CPIs.

Apesar de ter convencido os representantes da polícia, o substitutivo aprovado não contou com a concordância do Ministério Público. Pelo contrário: acendeu sinal de alerta máximo na instituição, que se mobilizou fortemente para evitar sua aprovação, num esforço que descreveremos mais adiante. O que motivou essa mobilização foi o fato de que, para o Ministério Público, restringir a possibilidade de apurar crimes atingia sua atribuição mais característica, comum à instituição em praticamente todos os países, além de ferir a autonomia tão cara ao modelo brasileiro, conforme havia registrado em nota técnica contra a PEC produzida pelo Conselho Nacional encarregado de fazer o controle externo do Ministério Público:

Como órgão constitucionalmente habilitado para a propositura da ação penal, conforme dispõe o art. 129, I, da Constituição da República, a atuação do Ministério Público não poderia ficar condicionada a nenhuma outra instância, sobretudo quando se fala de órgãos diretamente vinculados ao Poder Executivo, como são as polícias federal e civil (CNMP, 2012).

O que levou então a PEC a ser aprovada na comissão especial? Na avaliação dos presidentes das principais associações dos membros do Ministério Público ${ }^{5}$, foram três os

5 Entrevistas concedidas à autora por Alexandre Camanho, procurador regional da República e então presidente da Associação Nacional dos Procuradores da República (ANPR), e por Norma Angélica Cavalcanti, 
motivos. Em primeiro lugar, pela crescente atuação dos policiais no Congresso Nacional, tanto elegendo parlamentares integrantes da carreira, como praticando lobby agressivo em favor de proposições que não só buscavam ampliar suas atribuições, mas também restringir as prerrogativas do Ministério Público, considerado por muitos delegados como uma carreira rival, interessada em submeter a polícia. Isso apesar de ter crescido nos últimos anos e de predominarem entre as duas instituições, conforme declarações dos representantes do MP, o espírito e a prática da parceria. Em suma, o discurso institucional é de colaboração e cooperação, embora, nas práticas cotidianas e no campo relacional, as polícias e o MP operem no campo das lutas simbólicas, marcadas por disputas, conflitos e divergências de perspectivas e de interesses ${ }^{6}$. Como argumenta Bourdieu (1989), as lutas simbólicas se efetivam em disputas por prestígio, status e reconhecimento social e político.

O segundo motivo para aprovação da PEC teria sido o que os presidentes das entidades do MP reconheciam como um ensimesmamento da instituição, que teria reduzido a presença no Congresso Nacional em comparação com décadas anteriores. Uma das razões da retração seria a proibição da candidatura a cargos eletivos de membros que ingressaram na carreira depois de 1988. Outra, mais importante, seria uma postura de certa arrogância, que estaria levando promotores e procuradores a recusarem o diálogo com políticos, considerando-se superiores a eles em função de seu cargo técnico-jurídico, e tratando a política como uma atividade suspeita, seja de corrupção, seja de desatenção ao interesse público ou de ineficiência. "Há um discurso politicofóbico no Ministério Público. O político é o vagabundo", pensam muitos membros da instituição, segundo admite o presidente da ANPR à época7.

Nesse caso, chama atenção a tática do MP de usar como instrumento nas lutas simbólicas provas discursivas ancoradas na isenção, na neutralidade e no distanciamento da política partidária. Trata-se de um recurso para manter e reforçar o capital simbólico da reputação profissional, como agentes da promoção da justiça de forma "cega", sem viés político, ideológico ou partidário. A força moral da atuação dos procuradores e dos promotores do MP estaria diretamente associada a essa perspectiva, o que se enquadra na perspectiva da grandeza cívica, definida por Boltanski (2000) como aquela em que impera o interesse público.

O terceiro motivo seria a própria atuação do Ministério Público, processando agentes políticos - prefeitos, deputados etc. - não só por corrupção e outros crimes, mas também

\footnotetext{
promotora de Justiça na Bahia e presidente da Associação Nacional dos Membros do Ministério Público (Conamp), em 13 nov. 2014 e 2 dez. 2014, respectivamente.

6 Como exemplo dessas disputas, vale registrar o telegrama de apoio ao deputado Eduardo Cunha, presidente da Câmara dos Deputados e investigado pelo Ministério Público Federal, enviado pela Associação dos Delegados do Rio de Janeiro, que afirma: "De nossa parte temos combatido, sem tréguas, os excessos do Ministério Público no Brasil". Disponível em: <http://www.adepoldobrasil.org.br/rj-telegrama-de-desagravoenviado-ao-deputado-eduardo-cunha/>. Acesso em: 10 nov. 2015.

7 Entrevista concedida à autora por Alexandre Camanho, procurador regional da República e então presidente da Associação Nacional dos Procuradores da República (ANPR), em 13 nov. 2014.
} 
para fazê-los implementar políticas públicas que os membros do MP consideram estar de acordo com o estabelecido pela legislação. Mesmo membros do Ministério Público admitiam que tal atuação chegava a ser excessiva em vários casos. Tudo isso somado estaria levando a maioria dos deputados a se posicionar favoravelmente à PEC 37, não exatamente pelo seu texto, relativo à investigação criminal, mas com a motivação de frear, de alguma forma, a atuação do Ministério Público, percebida como abusiva. Trata-se de uma perspectiva em que se percebe claramente, mais uma vez, o potencial heurístico do conceito de lutas simbólicas de Pierre Bourdieu. Parlamentares e membros do MP atuam no campo das representações morais, calcadas em valores que apontam para perspectivas normativas, ou seja, o que deve ser considerado justo, coerente e adequado para o interesse público. Percebemos duas ordens de grandeza moral concorrentes nesse campo de lutas simbólicas. A atuação do MP situa-se no campo da grandeza cívica, como já foi ressaltado, e a atuação dos parlamentares é percebida como estando restrita ao âmbito da grandeza doméstica, ou seja, ancorada em valores de ordem pessoal, cujo capital é movido pelas relações personalizadas, típicas do mundo privado, como define Boltanski (2000).

Nessa linha de raciocínio Arantes já assinalava em pesquisa desenvolvida na virada do século:

No final, o que se percebe é que estamos diante de um mesmo e antigo paradoxo: a democracia política deficitária dá chance à emergência de um poder externo, pretensamente neutro ou apolítico, no qual são depositadas velhas e novas esperanças. Passada a euforia inicial da sua chegada, logo se percebe que um poder assim independente não pode seguir sem controles. No momento dessa descoberta, o problema da representação se recoloca e a Política toma o seu lugar novamente (Arantes, 2000, p. 4).

No início do ano parlamentar de 2013, integrantes do Ministério Público davam como certa a aprovação da PEC no Plenário da Câmara. Para piorar a situação, o procuradorgeral da República, Roberto Gurgel, denunciou ao Supremo Tribunal Federal o senador Renan Calheiros, por peculato e outros crimes, poucos dias antes da eleição para presidência do Senado. Calheiros era candidato ao cargo e acabou eleito. A denúncia provocou forte reação do Congresso, que atribuiu motivação política ao seu oferecimento naquele momento. Contudo, a mobilização maciça contra a proposta - envolvendo centenas de visitas a parlamentares, contatos com a imprensa e com entidades da sociedade civil, atos públicos e ações nas mídias sociais -, angariou apoio suficiente para levar o então presidente da Câmara dos Deputados, Henrique Eduardo Alves, a criar, em 30 de abril de 2013, um inédito grupo de trabalho, integrado por representantes da Câmara, do Senado, da polícia, do Ministério Público e do Ministério da Justiça, com o objetivo de formular uma alternativa consensual à PEC, dentro de 30 dias. Em 27 de maio o grupo pediu mais 30 dias de prazo. Em 7 de junho, o presidente da Câmara afirmou publicamente que colocaria a PEC em votação no dia 26 daquele mês. 
A estratégia dos representantes do Ministério Público no grupo de trabalho era ganhar tempo para evitar que a PEC fosse colocada em votação. Apesar do apoio obtido dentro e principalmente fora do Congresso, a avaliação era de que a maioria dos deputados ainda via na proposta um freio desejável à atuação do Ministério Público e votaria pela aprovação. Mesmo assim, os representantes do MP não cogitavam ceder à posição dos representantes dos policiais. Se os primeiros concordavam em regulamentar a duração e garantias de publicidade das investigações, entre outros pontos já existentes em normas internas ${ }^{8}$, os últimos somente aceitavam restringir a investigação por não policiais a casos excepcionais. No dia 6 de junho, a presidente em exercício da Conamp, Norma Cavalcanti, entregou ao presidente da Câmara uma proposta formulada por representantes do MP para regulamentar a investigação. Alguns dias depois, a proposta passou a ser amplamente distribuída a deputados e senadores - "planfletada", segundo o presidente da ANPR. No dia 13, o grupo de trabalho concluiu seu texto, que não diferia significativamente do que havia sido aprovado pela comissão especial, ou seja, ainda restringia a prerrogativa de investigação criminal às polícias, com exceções.

Então vieram as manifestações e a derrubada da PEC 37 apareceu entre as reivindicações. Cartazes com esse pedido bastante específico foram logo destacados pela imprensa. No dia 19 de junho, os representantes do MP no grupo de trabalho se posicionaram oficialmente contra o texto formulado no grupo. Na véspera, a deputada Marina Sant'Anna, do PT de Goiás, tinha apresentado o Projeto de Lei 5776/2013, para regulamentar a investigação criminal, baseado em propostas do Ministério Público. No dia 19, o deputado Onyx Lorenzoni, do Democratas do Rio Grande do Sul, apresentou outro projeto sobre o mesmo tema. No dia 24, foi a vez do deputado Arthur Oliveira Maia, do PMDB da Bahia, e no dia 25, do deputado Carlos Sampaio, do PSDB de São Paulo, protocolarem propostas de regulamentação da investigação criminal. Todas elas incluíam a possibilidade de investigação pelo Ministério Público. A manifestação desses parlamentares de diferentes partidos a favor dos argumentos do MP é relevante para reforçar o caráter pluralista do parlamento, como um palco de lutas simbólicas entre os próprios agentes do corpo legislativo. Apesar de ter sido dominante a voz dos parlamentares alinhados ao discurso dos policiais, o registro reforça o caráter da complexidade das lutas simbólicas, uma vez que não se trata de algo estático e com limites e perspectivas definidos de forma objetiva. Como argumenta Bourdieu (1989), as lutas simbólicas são dinâmicas e nem sempre passíveis de caracterização objetiva.

Segundo relato dos representantes do MP entrevistados, agora eram os policiais que queriam adiar a votação da PEC, marcada para 26 de junho. Ainda no dia 25, a versão original da PEC - e não o relatório aprovado pela comissão especial - foi colocada em

8 Resolução 13/2006 do Conselho Nacional do Ministério Público. Disponível em: <http://www.cnmp.mp.br/portal/resolucoes/2915-resolucao-13?highlight=WyJjcmltaW5hbCJd>. Acesso em: 22 mar. 2015. 
votação no Plenário da Câmara e rejeitada por 430 votos contra nove, com encaminhamento contrário dos líderes de todos os partidos. Na análise de Arantes, o Ministério Público havia reassumido o protagonismo na discussão legislativa de suas atribuições, depois de se ver acuado pelo crescimento do prestígio da polícia nos anos anteriores:

\begin{abstract}
É nesse contexto que a instituição que parece ter sete vidas tomou a decisão estratégica de sair pela frente e não limitar-se à defesa do status quo em torno da matéria. Refiro-me ao Projeto de Lei 5.776/2013, que tramita hoje no Congresso sob o patrocínio do próprio MP. A título de promover uma nova e detalhada regulação das atividades de investigação, o projeto cria a figura do inquérito penal ao lado do inquérito policial. Este, tradicional, continuaria sendo presidido pelas polícias. Aquele, novo, ficaria a cargo do MP, que teria assim finalmente reconhecida e institucionalizada sua prerrogativa de investigar (Arantes, 2013) ${ }^{9}$.
\end{abstract}

\title{
Dos gabinetes às ruas
}

Além do que já foi exposto anteriormente sobre as controvérsias, este artigo acompanha a premissa adotada por Maia (2011, p. 260-261) de que a existência de interesses divergentes na sociedade não permite determinar previamente o que seriam definições razoáveis e legítimas. Ao contrário, "o debate conduzido democraticamente entre os envolvidos e concernidos é o meio apropriado para estabelecer, num dado momento, o que pode ser reconhecido como o interesse público ou bem comum, em relação a uma questão específica".

Dessa maneira, torna-se fundamental para a teoria política compreender como se concebe e como se desenvolve, na prática, um debate democrático, preocupação que é objeto da abordagem deliberativa e que interessa a este artigo. Segundo a mesma autora (Maia et al., 2014, p. 203-205), a deliberação é um processo ampliado, que se dá em múltiplas esferas e cujos atores produzem sentido a partir de trocas argumentativas realizadas não só em interações face a face, mas também por meio de opiniões e discursos que circulam na arena midiática. Assim, pode-se afirmar que a possibilidade de acesso a essa arena e a atuação para obter espaço nela são decisivas para definir o sucesso dos pontos de vista de determinados grupos num debate. Afinal, todo processo deliberativo envolve disputas discursivas, elemento básico das controvérsias públicas e das lutas simbólicas, conforme já foi abordado anteriormente.

\footnotetext{
${ }^{9}$ O PL 5776/2013 foi distribuído às Comissões de Constituição e Justiça e de Segurança Pública da Câmara. Não chegou a ser votado em nenhuma delas e foi arquivado em 2014, com o final da legislatura, tendo sido desarquivado em 2015, por requerimento do deputado Onyx Lorenzoni. Os projetos apresentados na mesma época e outros haviam sido apensados a ele, para tramitar conjuntamente.
} 
No caso da PEC 37, o exame da campanha desenvolvida pelo Ministério Público ao longo do primeiro semestre de 2013 e a análise da cobertura feita pela imprensa podem ajudar a compreender como a rejeição da proposta surgiu entre as bandeiras das manifestações de junho e acabou sendo atendida pela Câmara dos Deputados. Ao contrário do que pode ter parecido na época a alguns analistas (Arantes, 2013), a PEC 37 não despontou subitamente na esfera pública durante as manifestações, nem foi apelidada de "PEC da impunidade" pelos manifestantes. A adesão dos manifestantes à causa do MP reforça o caráter dinâmico das lutas simbólicas e de como as controvérsias públicas podem provocar efeitos de consenso e dissenso na sociedade. Demonstra ainda a eficácia simbólica do discurso público do MP e de sua atuação nesse campo de disputas simbólicas, ao conquistar a simpatia dos manifestantes, como consequência do engajamento e ativismo da imprensa, aliada do MP na batalha de conquista da opinião pública, além da mobilização de categorias e organizações da sociedade civil. Esse efeito de consonância de perspectivas entre imprensa e opinião pública, via manifestantes, certamente foi um fator relevante na decisão final dos parlamentares pela rejeição da PEC 37.

A pesquisa permite sustentar que no final de 2012 os integrantes do Ministério Público avaliaram ter posição minoritária na comissão especial criada para analisar a emenda, a despeito do apoio demonstrado pela maioria dos especialistas da área jurídica ouvidos em audiências públicas pela comissão, e viram como única possibilidade de impedir a aprovação da PEC: obter apoio da imprensa e da opinião pública, para mudar a posição dos parlamentares no Plenário da Câmara. Diante dessa avaliação, as associações de membros do Ministério Público lançaram em Brasília, em 11 de dezembro, alguns dias antes da aprovação da PEC na comissão, a campanha "Brasil contra a impunidade", em que a proposta ganhava a alcunha de "PEC da impunidade": 
Figura 1

Modelo de folheto distribuído no Congresso Nacional e em eventos promovidos pelas associações do Ministério Público em todo o país, entre dezembro de 2012 e junho de 2013.

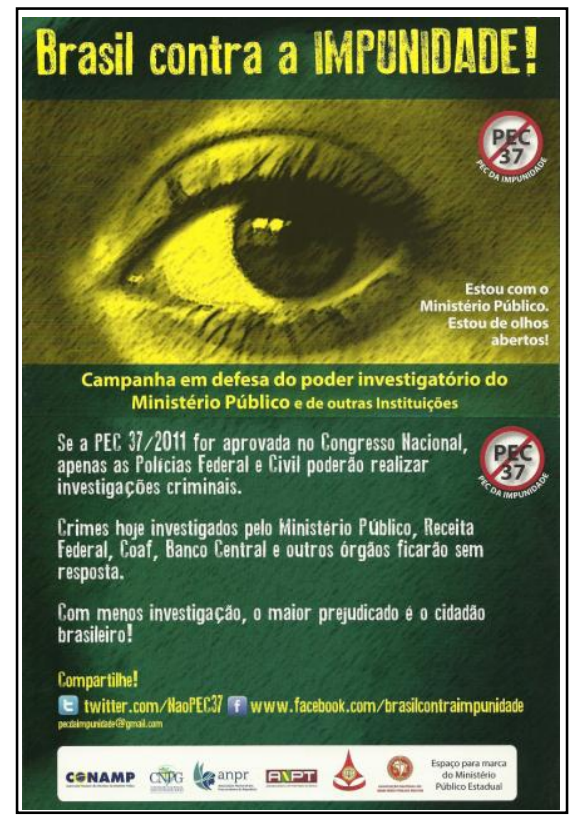

Fonte: Associação Nacional dos Membros do Ministério Público (Conamp).

A estratégia discursiva adotada na campanha produziu eficácia porque remeteu para a memória do público e para as representações já construídas sobre a impunidade no Brasil pela própria mídia. Ao realizar a campanha, os representantes do MP atuaram como agentes midiáticos, recorrendo a uma campanha publicitária nos moldes a que o público já está habituado. Em outras palavras, o MP usou as formas simbólicas de modo adequado ao caso, com o propósito de fortalecer sua atuação nas lutas simbólicas em torno das controvérsias já mencionadas.

$\mathrm{Na}$ verdade, as associações do MP já estavam atuando contra a aprovação da PEC pelo menos desde abril de 2012, quando a comissão especial para examinar a proposta foi instalada. Mas até perto do final do ano esse ainda era um assunto entre os muitos acompanhados pelas organizações, perdendo no interesse dos integrantes do MP para os temas ligados à remuneração, por exemplo. Agora, a PEC ganhava prioridade. O objetivo da campanha lançada em dezembro era começar pelos estados, alcançando imprensa, organizações da sociedade civil, governo e parlamentares, para culminar em abril. Observa-se aqui como os representantes articulam uma ação política envolvendo uma rede de atores aliados, em vez de agir isoladamente. Além de garantir a dessingularização da causa, essa estratégia permitiu a ampliação da visibilidade e da discutibilidade do assunto, 
o que implicou maior inserção social do tema no debate público, tanto pela arena midiática, quanto pelas redes institucionais e fóruns de discussão protagonizados pelos atores citados.

O material publicitário foi criado por uma agência contratada em parceria pela Conamp e ANPR. A veiculação em mídia foi gratuita, na grande maioria dos casos, feita em parceria com as empresas de comunicação. A negociação, reprodução e distribuição foram feitas pelas associações estaduais. Os órgãos do Ministério Público também se envolveram diretamente, conforme se verificou no questionário respondido por 24 dos 30 órgãos para esta pesquisa. Todos os respondentes atuaram na campanha, de diversas formas, como detalha o Gráfico 1 :

\section{Gráfico 1}

Ações de comunicação desenvolvidas pelos órgãos e associações do Ministério Público na campanha contra a PEC 37

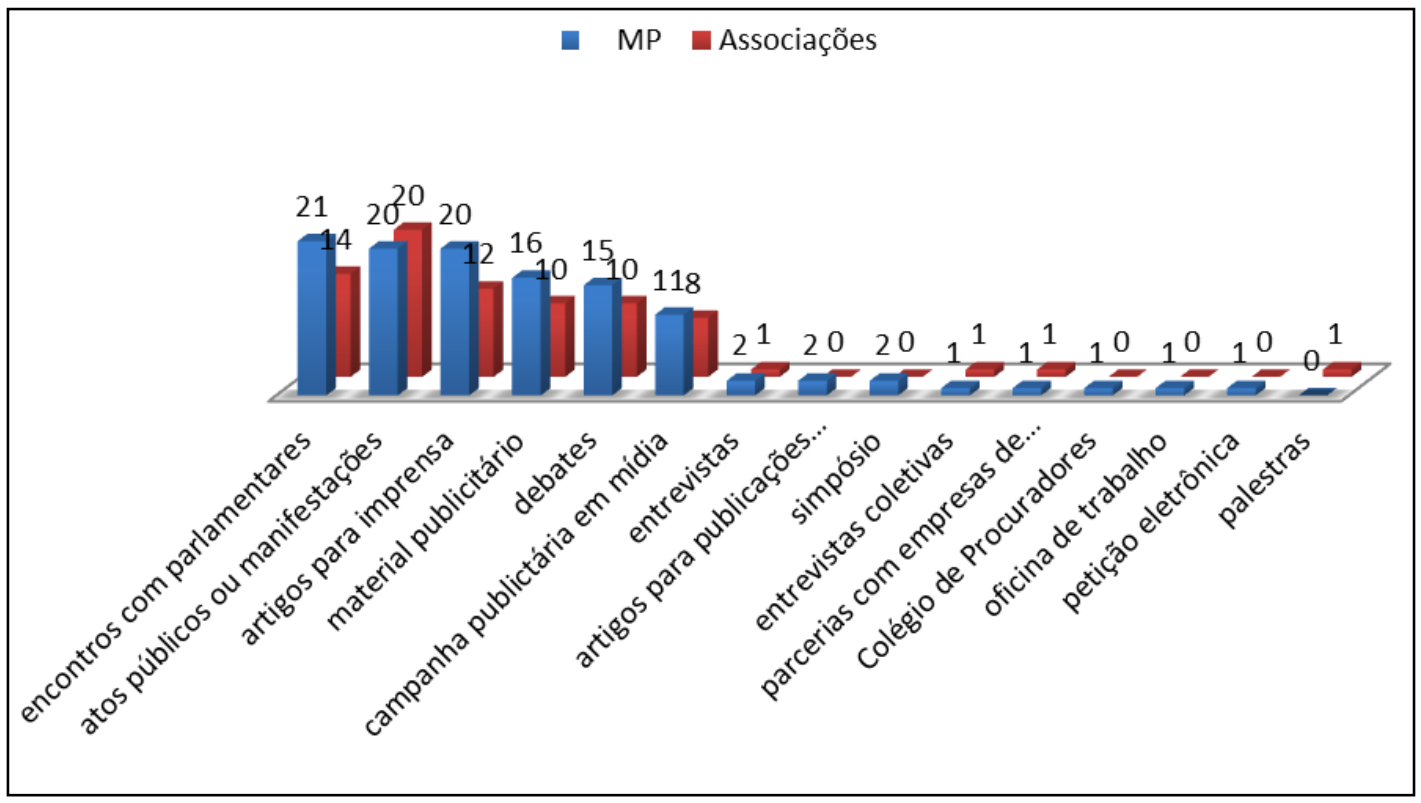

Fonte: Dados apurados na pesquisa.

Os dados mostram como foram diversificadas as estratégias de comunicação dos representantes do MP, apesar da concentração em alguns itens de maior expressão. Encontros com parlamentares, atos públicos ou manifestações, artigos para a imprensa, material publicitário de comunicação direta, debates e veiculação de material publicitário na mídia foram os instrumentos utilizados com maior frequência. Os encontros com parlamentares foram individuais ou com grupos e bancadas - partidárias ou estaduais -, em Brasília e nos estados. O objetivo era tanto para reforçar os vínculos com os deputados 
contrários à PEC e estimulá-los a influenciar outros parlamentares ainda sem opinião formada sobre o tema, como buscar diretamente esses parlamentares, visto que no universo dos 513 deputados havia um grande número que ainda não tinha se manifestado publicamente sobre a PEC 37. O investimento em atos públicos e manifestações se justifica pela possibilidade de cobertura da mídia e pelo potencial de conquista de apoio da opinião pública. Os artigos escritos para a imprensa acabam por atender à demanda dos próprios veículos, visto que era notório o apoio da imprensa à rejeição da PEC. Nesses casos, para manter sua suposta postura de imparcialidade, as mídias costumam recorrer a vozes externas, com um duplo objetivo: mostrar-se ao público como um veículo pluralista, mas, ao mesmo tempo, encaixar determinadas opiniões para reforçar sua política editorial. Tal postura enquadra-se no horizonte analítico de Pierre Bourdieu (1997) referente às estruturas simbólicas invisíveis que sustentam os modelos de cobertura da imprensa e Ihes garantem estabilidade e repetição, contribuindo para a reprodução das formas simbólicas expressas no campo político.

De acordo com o planejado pelas associações, que passaram a se reunir semanalmente em Brasília, dezenas de eventos se sucederam durante os primeiros meses de 2013, ancorados no que os entrevistados para a pesquisa que deu origem a este artigo caracterizaram como "a maior mobilização do Ministério Público desde a Constituinte de $1988^{10}$ e "o momento em que demos o melhor de nós"11. Foram seminários, palestras, debates em escolas, atos públicos, panfletagens e posts em redes sociais, como o que segue:

\footnotetext{
${ }^{10}$ Entrevista concedida à autora por Norma Angélica Cavalcanti, promotora de Justiça na Bahia e presidente da Associação Nacional dos Membros do Ministério Público (Conamp), em 2 dez. 2014.

11 Entrevista do secretário especial do Gabinete do Procurador-Geral da República, procurador regional da República Danilo Pinheiro Dias, concedida à autora em 12 nov. 2014.
} 
Figura 2

\section{Reprodução de cartaz em conta de promotor de Justiça no Facebook convoca ato público contra a PEC 37 em Divinópolis (MG)}

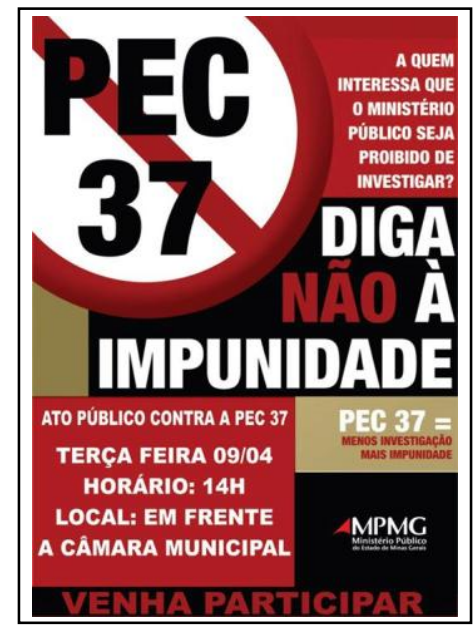

Fonte: <https://www.facebook.com/case.fortes>. Acesso em: 22 mar. 2015.

Ainda segundo os entrevistados, toda semana grupos de promotores e procuradores desembarcavam em Brasília para percorrer o Congresso Nacional, visitando deputados e senadores para verificar sua intenção de voto e defender a posição do MP. Os contatos renderam apoios que eram divulgados para buscar mais adesões, dentro e fora do Congresso, uma estratégia para conferir maior visibilidade ao poder de agência do MP, reforçar as redes de apoio e ampliar a inserção do debate na sociedade. A Conamp chegou a produzir um documento de 90 páginas, distribuído no Congresso Nacional, que reuniu notas técnicas e moções contrárias à PEC de instituições como a CNBB, a Associação Brasileira de Imprensa, a Anistia Internacional, o Conselho Nacional de Justiça, a Secretaria de Reforma do Judiciário do Ministério da Justiça, a Associação dos Juízes Federais, o Conselho Nacional de Comandantes Gerais das Polícias Militares e Corpos de Bombeiros Militares, a Federação Nacional de Policiais Federais (que costuma atuar em oposição aos delegados), a Maçonaria, o Conselho Federal de Medicina, dezenas de associações de moradores e de Câmaras Municipais e diversos organismos internacionais de promotores e juízes.

A mobilização na internet e especificamente nas mídias sociais também foi intensa, incluindo a contratação de empresa especializada pelas associações. Este artigo não se concentrou na análise desse ambiente, mas vale a pena mencionar alguns dados que indicam o resultado das ações dos integrantes do Ministério Público e dos simpatizantes de sua causa. A enquete realizada pela Câmara dos Deputados sobre a participação do Ministério Público em investigações criminais, durante a tramitação da PEC, obteve o maior 
número de participantes até então - 230.386 votos -, sendo $87,24 \%$ contrários à proposta. A enquete continua sendo a campeã de participação entre as encerradas pela Câmara e fica em quarto lugar, considerando as ainda ativas ${ }^{12}$. O Ministério Público de São Paulo destacou-se nesse campo e promoveu duas ações bem-sucedidas, com apoio das associações e dos demais MPs. Um abaixo-assinado digital contra a PEC 37 dirigido a deputados federais e senadores foi organizado por meio da plataforma change.org e reuniu 460.877 assinaturas - mais do que dobrando a meta de 200 mil a ser obtida. Em 22 de abril, o tuitaço \#NAOPEC37 alcançou o sétimo lugar nos trending topics do dia, com 17 mil tuítes originais (Figura 3). Todas essas estratégias reforçam o potencial de inserção social, aceitação e adesão da perspectiva argumentativa dos representantes do MP. Dessa forma, os argumentos deixaram de ser exclusivos da instituição MP e passaram a ser adotados pelos cidadãos conectados às redes sociais digitais, por entidades da sociedade civil contrárias à aprovação da PEC 37. Esse efeito não conseguiu ser afetado pelas operações discursivas dos opositores do MP. Os delegados de polícia e seus representantes no parlamento passaram a figurar nesse campo de lutas simbólicas como vozes isoladas e comprometidas com a "velha política", ancorada em valores que sustentam o mundo regido pela grandeza doméstica, nos termos de Boltanski (2000).

\section{Figura 3 \\ Imagem veiculada no Facebook e no Twitter convida para o tuitaço contra a PEC 37}

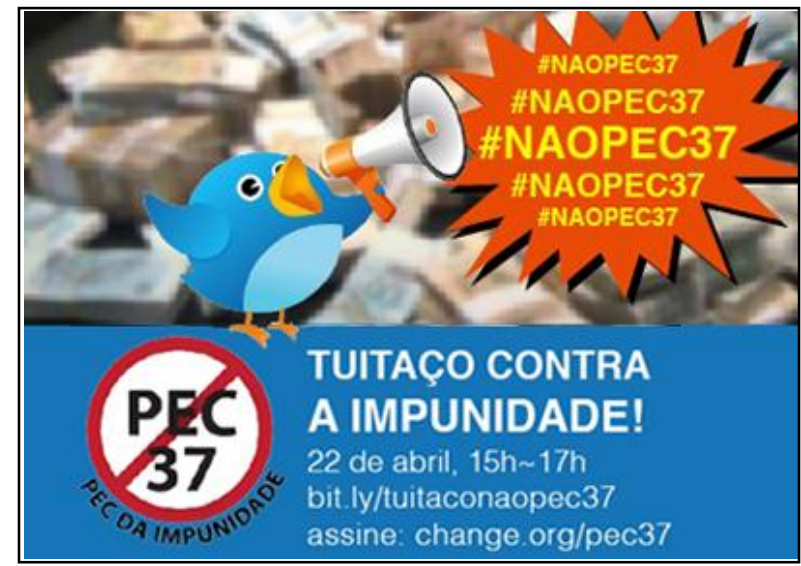

Fonte: Ministério Público de São Paulo.

\footnotetext{
${ }^{12}$ A pergunta era: "Você concorda que investigações criminais sejam realizadas somente pela Polícia e não mais pelo Ministério Público (PEC 37/11)? (Clique aqui para saber mais). E as opções: Não. Acho que o MP deve poder investigar quando julgar necessário. Sim, concordo. Em parte. Acho que o MP deve investigar somente casos específicos". Disponível em: <http://www2.camara.leg.br/enquetes/pesquisaEnquete/>. Acesso em: 22 mar. 2015.
} 
Na manhã do dia 24 de abril, cerca de mil pessoas lotaram o auditório do Ministério Público do Distrito Federal, em Brasília, para participar do $1^{\circ}$ Simpósio contra a impunidade, nome oficial do ato programado para coroar a campanha. À tarde, uma passeata se dirigiu ao Congresso Nacional, onde um abaixo-assinado contrário à PEC, com cerca de 500 mil adesões, foi entregue ao presidente da Câmara dos Deputados. Em 30 de abril, Henrique Alves criou o grupo de trabalho sobre a PEC, o que fez com que as negociações entrassem em novo momento e aumentou a cobertura na imprensa, conforme veremos na próxima seção, "O papel da mídia".

O envolvimento oficial das instituições merece registro. O Ministério Público Federal criou, por meio de portaria, um gabinete de crise para acompanhar a tramitação da PEC. Por meio do contrato mantido com uma agência de publicidade, desenvolveu uma campanha específica, que teve veiculação paga no mês de junho, em alguns dos principais veículos de comunicação do país. Uma área especial desenvolvida no site da instituição publicou 107 notícias, apenas entre maio e junho de 2013. A publicação de material nos endereços institucionais na internet e nas contas em mídias sociais foi a regra. O Ministério Público do Ceará, outro exemplo, publicou em seu site, entre março e junho de 2013, 68 títulos sobre o assunto, como:

- "Câmara de Granja se manifesta contra a PEC 37" (11 jun. 2013);

- "MP busca apoio de pastores contra a PEC 37" (17 maio 2013);

- "Maria da Penha faz declaração contra a PEC 37" (17 maio 2013);

- "Alunos da Unichristus ampliam debate sobre PEC 37" (19 abr. 2013);

- "TV Cidade se engaja na campanha contra a PEC 37" (17 abr. 2013)

Assim, quando os eventos de junho se iniciaram, com a manifestação contra a Copa das Confederações e contra o aumento das passagens realizada em São Paulo, no dia 10, a PEC 37 já era um tema em discussão no Brasil, mesmo se com alcance menor do que atingiu naqueles poucos dias. No dia 13, quando outra manifestação realizada em São Paulo foi violentamente reprimida, uma enquete do portal UOL a respeito da PEC 37 tinha alcançado 188 mil votos, sendo $95,65 \%$ contrários à proposta ${ }^{14}$. Ou seja, quando o número de manifestantes cresceu de poucas centenas para dezenas de milhares, no dia 17, e a pauta se alargou, extrapolando a questão urbana para abranger insatisfações múltiplas e difusas, a bandeira contra a PEC 37 estava disponível, em circulação nas mesmas redes sociais que haviam catalisado o início dos protestos e na imprensa que os amplificou. Mais importante, o Ministério Público havia conseguido difundir em círculos bastante amplos a ideia de que a PEC 37 favorecia a impunidade e a corrupção, traduzindo uma questão

\footnotetext{
13 Todos os títulos citados estão disponíveis em:

<http://www.mpce.mp.br/servicos/asscom/destaques2.asp?cd=2397>. Acesso em: 15 nov. 2014.

${ }^{14}$ A enquete perguntava: Você concorda com a Proposta de Emenda à Constituição (PEC 37) que limita a atuação criminal do Ministério Público? (Conamp, 2014, p. 197).
} 
corporativa e institucional para o campo do interesse público. Nas palavras do presidente da ANPR:

\begin{abstract}
Jamais saberemos qual seria a realidade se o povo não tivesse ido para a rua. A turma que foi para a rua é a turma que fica rastreando rede social e que lá pelas tantas viu que tinha uma grande injustiça que estava sendo engendrada no país e que dependia do Congresso Nacional. Uma frase que nós colocamos lá do Joaquim Barbosa teve quantos? 800 mil compartilhamentos ${ }^{15}$.
\end{abstract}

Os dirigentes das associações do Ministério Público relatam que, quando começaram as manifestações eles passaram a ser procurados por líderes comunitários de várias partes do país que solicitavam material contra a PEC. "Comecei a receber telefonemas do tipo: Doutor, queremos fazer umas faixas contra a PEC 37, estou aqui em Vitória. E eu: Pago. Vou Ihe mandar as fotos, o senhor vai ver hoje no Jornal Nacional" ${ }^{16}$. E que parlamentares e representantes das polícias no grupo de trabalho da Câmara chegaram a pedir que o MP parasse de se referir à proposta como "PEC da impunidade". O resultado é que a PEC 37 aparece entre os temas mencionados nas redes sociais em relação com os protestos desde o dia 16 de junho, alcançando o primeiro lugar na madrugada do dia 26, com $12,8 \%$ das menções, conforme monitoramento feito pela plataforma Causa Brasil ${ }^{17}$.

Os dados apresentados nos permitem concluir que a intensa mobilização dos membros do Ministério Público, com apoio de entidades da sociedade civil e da imprensa, que detalharemos a seguir, permitiu que o tema chegasse às ruas. Discordamos da avaliação de Pinto (2014, p.3) de que "esta demanda e a forma como apareceu nas manifestações diferia muito do que acontecia de modo geral nas ruas, indicando um possível aparelhamento". Ao contrário, acreditamos que as organizações dos membros do $\mathrm{MP}$, de maneira similar aos movimentos pelo passe livre, conseguiram conectar demandas específicas com inquietações difusas na sociedade - no caso do MP, a rejeição à corrupção na política - obtendo apoio mais amplo para suas causas.

\title{
O papel da mídia
}

A imprensa tem sido uma aliada do Ministério Público nos momentos de luta simbólica em que ele é atacado. Não é difícil perceber que os interesses costumam convergir (Nascimento, 2007). Quando se cogita proibir promotores de falar sobre processos em andamento, como aconteceu com a Lei da Mordaça, no final dos anos 1990,

\footnotetext{
15 Entrevista concedida à autora por Alexandre Camanho, procurador regional da República e então presidente da Associação Nacional dos Procuradores da República (ANPR), em 13 nov. 2014.

16 Entrevista concedida à autora por Alexandre Camanho, procurador regional da República e então presidente da Associação Nacional dos Procuradores da República (ANPR), em 13 nov. 2014.

17 Disponível em: <http://www.causabrasil.com.br>. Acesso em: 23 nov. 2014.
} 
está-se buscando, na verdade, evitar que as informações cheguem à imprensa. Cabe ressaltar que o MP tem sido, ao longo de sua história, uma fonte perita e confiável para o jornalismo investigativo. Trata-se, portanto, de um órgão que auxilia e fortalece o trabalho da imprensa, por isso percebe-se a parceria nesse interplay midiático de atores, em que não se pode atribuir tudo ao papel da imprensa, uma vez que as mídias atuam em cooperação ou competição com outros atores (Elmelund-Praestekaer e Wien, 2008).

No caso da PEC 37, o objeto da disputa - o poder de investigar - também tem ligações com o jornalismo. Assim, não é de estranhar que os veículos de comunicação procurados pelo MP tenham, em sua maioria, afirmado que apoiariam a posição contrária à PEC, conforme relato dos dirigentes entrevistados: "A imprensa fechou questão. (...) $O$ pessoal da Globo veio aqui e disse: não se preocupe, nós estamos fechados. (...) Isso criou um clima brutalmente favorável" ${ }^{18}$; e que a maior parte do que a imprensa publicou sobre PEC 37 tenha sido efetivamente contrário à proposta, conforme demonstraremos a seguir. Essa ação de alinhamento da imprensa à postura do MP tem relação direta com a convergência de status e de papéis, cujo ponto focal é o ato de investigar e sua relevância no âmbito da democracia e da liberdade de expressão. Investigar remete a uma ordem simbólica cujas representações sociais já consolidadas no imaginário social estão relacionadas a um compromisso com a "verdade dos fatos", com operações cujo objetivo é trazer luz sobre situações de suspeita, sobre casos de denúncia e de desvio de conduta e falta de decoro dos agentes públicos. Essa é a base da atuação do MP e do jornalismo investigativo. Ambos operam sob a lógica de trabalho moral ${ }^{19}$, que se expressa na organização temporal de uma narrativa que se apresenta ao público como sendo objetiva e imparcial, ou seja, "colada aos fatos, apresentada como não posicionada e pluralista, naturalizando recortes e sentidos na exposição dos fatos" (Biroli e Mantovani, 2014, p. 211-212). Esse trabalho moral é definido a partir de técnicas de poder e disciplinas do olhar (Biroli, 2007). Cabe ressaltar ainda que as disciplinas do olhar são fundamentais nas atividades de investigação, seja do MP, seja dos jornalistas.

Merece um exame mais detido a forma como o apoio da imprensa ao MP se manifestou no caso específico da controvérsia sobre o poder de investigar. Para a pesquisa, levantamos 351 textos publicados em três jornais e quatro revistas, desde janeiro de 2013 até junho de 2013. Dos três jornais estudados, dois se posicionaram contrariamente à PEC em editoriais (Gráfico 2): Folha de S. Paulo e O Globo, com destaque para o número de manifestações de $O$ Globo (sete editoriais) e também para o fato de o jornal ter sido o primeiro a se posicionar, em dezembro de 2012, quando a PEC ainda era discutida na

\footnotetext{
18 Entrevista concedida à autora por Alexandre Camanho, procurador regional da República e então presidente da Associação Nacional dos Procuradores da República (ANPR), em 13 nov. 2014.

${ }_{19}$ A expressão original é usada por Ettema e Glasser (1998) e aplicada por Biroli e Montovani (2014). Esses autores referem-se exclusivamente ao campo jornalístico. Em nosso entendimento, porém, no paralelo que fazem entre jornalismo investigativo e as investigações do Ministério Público, acreditamos que seja possível estender as considerações também ao MP.
} 
comissão especial e na véspera do lançamento da campanha do MP. Se o título desse primeiro editorial pode ser considerado neutro - Papel constitucional -, a argumentação se alinha ao Ministério Público, destacando a independência da instituição e já respondendo às objeções levantadas pelos defensores da PEC:

O direito estendido ao MP de promover diligências não implica retirar essa prerrogativa das polícias. Apenas acaba com o monopólio policial das investigações criminais, perigoso porque tais corporações, ligadas diretamente ao Poder Executivo, nem sempre são blindadas contra pressões de grupos que não respeitam os limites entre interesses pessoais (ou de governos) e as soberanas razões de Estado. Não faltam exemplos disso no país.

Sem dúvida, procuradores e promotores estão sujeitos a cometer excessos. Mas deslizes não são da natureza da função. Não se justifica condenar o todo por eventuais abusos de uma parte que atue em desconformidade com o que é claramente definido por regras funcionais. Ademais, desvios de conduta, seja no MP, nas polícias ou em outros organismos do poder público, são passíveis de ações correcionais, pelo Conselho Nacional do MP. Que deve ser mais atuante, é verdade.

A PEC 37 ainda passará pelos plenários da Câmara e do Senado. Nessas instâncias é crucial que seja derrotada a proposta, uma tentativa de contrabandear para a Constituição, de forma perigosa, porta aberta para a impunidade. Bastam as que já existem (O Globo, $10 \mathrm{dez}$. 2012).

A mesma linha é adotada pela Folha de S. Paulo no primeiro editorial sobre o tema, Projeto de impunidade, datado de abril de 2013:

Perde-se, de saída, a independência desse órgão nas investigações, um trunfo nada desprezível. Basta lembrar que os chefes das polícias sempre estão submetidos ao Poder Executivo, não raras vezes alvo dos inquéritos.

Se não se pode negar que o Ministério Público comete alguns abusos, que se implementem balizas para manter a atuação do órgão dentro de limites razoáveis.

Não é aceitável que, a fim de corrigir excessos, se sacrifique a experiência acumulada pelo Ministério Público com o trabalho ora internacionalmente reconhecido. O despropósito só faz dar mais razão ao apelido de PEC da impunidade (Folha de S. Paulo, 30 abr. 2013).

Apenas $O$ Estado de $S$. Paulo se posicionou, em três editoriais, favoravelmente à PEC (mais um neutro). Um trecho do primeiro deles, datado de 11 de abril de 2013, exemplifica a utilização de argumentos próximos daqueles empregados pela polícia e também pela OAB na defesa da PEC 37: 
A conversão do Ministério Público num órgão superdimensionado compromete o salutar princípio do equilíbrio entre os Poderes. O País muito ganharia se o MP e os órgãos policiais exercessem seus respectivos papéis com eficiência - o que proporcionaria uma Justiça menos sujeita a improvisações e a rivalidades corporativas.

Gráfico 2

Jornais - Posição das fontes sobre a PEC 37

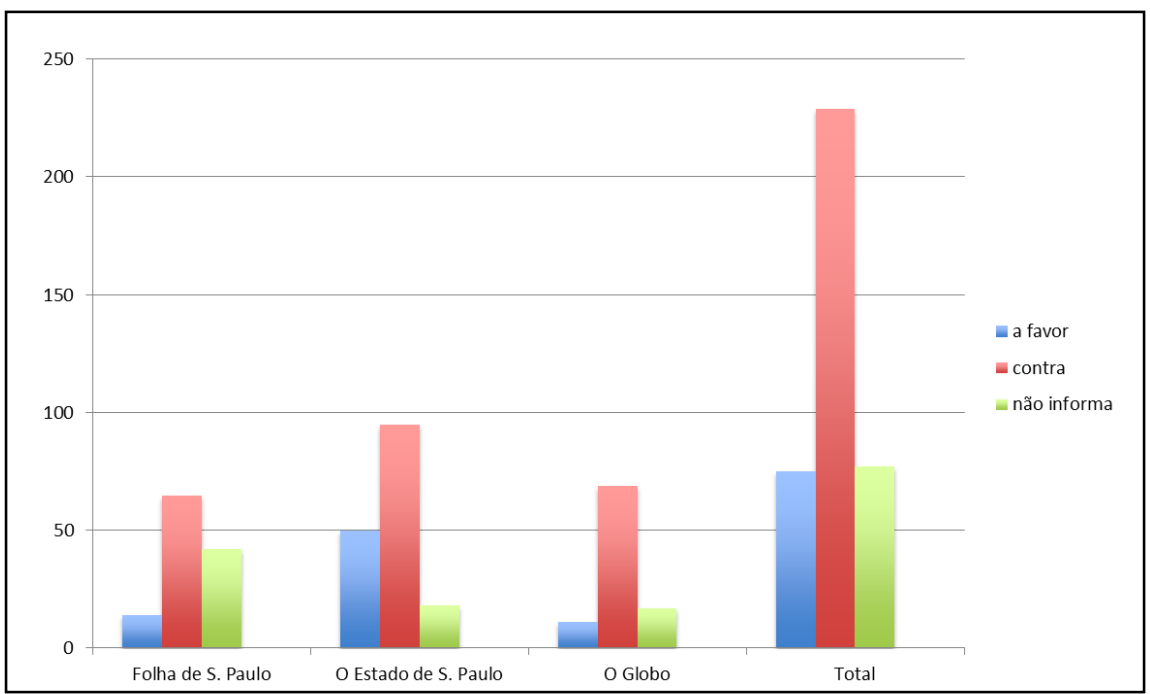

Fonte: Dados da pesquisa.

Os editoriais são relevantes como objeto de estudo em casos de controvérsias na arena midiática por se tratar da voz institucional dos veículos, um ponto de vista privado sobre a conduta dos agentes públicos e sobre a atuação política das instituições (Krieger, 1990). No espaço discursivo de um jornal cumpre ainda a função de demarcador temático da relevância política, social, econômica ou cultural de um fato, uma vez que se trata de um texto argumentativo, com a chancela opinativa do veículo, cuja função é expressar perante os leitores e anunciantes a opinião do órgão editor sobre os temas em exame (Barros, 2000).

A posição opinativa predominantemente contrária à PEC se repetiu nos artigos de autores convidados, reforçando a tese de que a imprensa atuou como aliada do MP nas lutas simbólicas em torno da PEC 37. Mais uma vez, O Estado de S. Paulo foi a exceção (Gráfico 3). Esse posicionamento poderia requerer um exame qualitativo mais detalhado para compreender as razões da atuação diferenciada do Estadão, o que não será possível 
nos limites deste artigo. Da mesma forma, caberia aprofundar as razões que explicam o engajamento maior de $O$ Globo, como se observa no Gráfico 3:

\section{Gráfico 3}

Posição dos artigos publicados nos jornais sobre a PEC 37

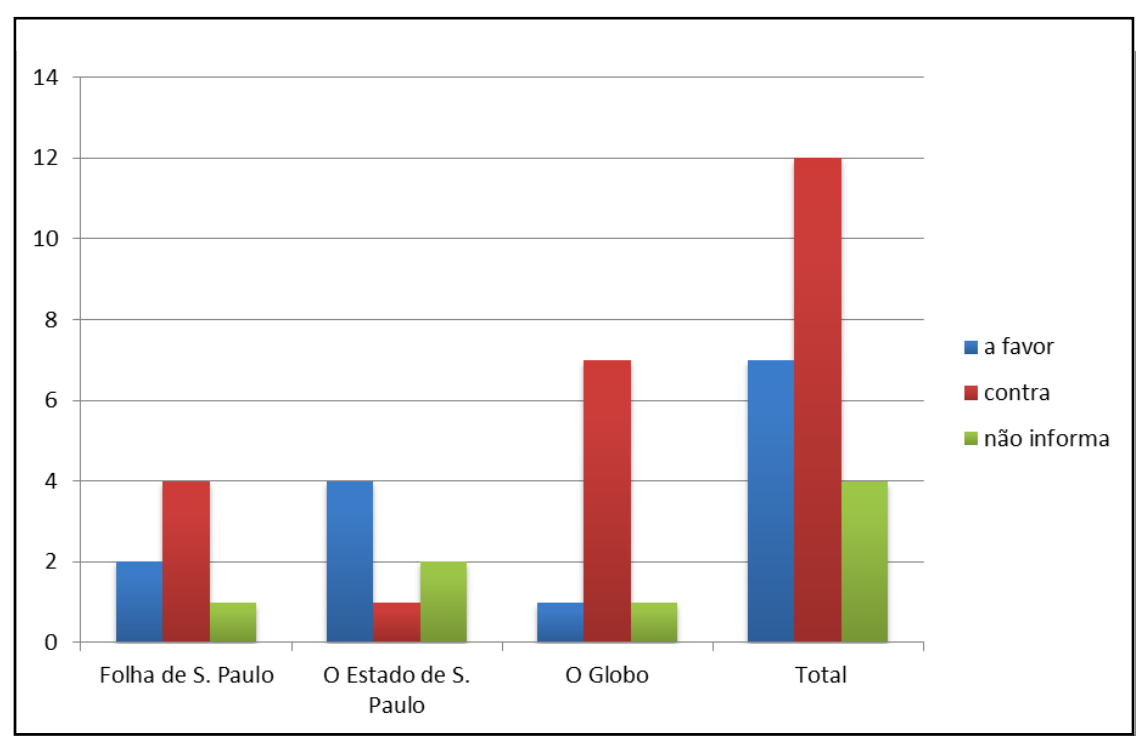

Fonte: Dados da pesquisa.

Os argumentos favoráveis à PEC se concentram em dois pontos: o excesso de poderes atribuídos ao Ministério Público e a necessidade de separar a função de investigar da atribuição de acusar: "O MP pode muito, mas não deve poder tudo!", argumenta Guilherme Batochio, escrevendo em nome da Ordem dos Advogados do Brasil (O Estado de S. Paulo, 11 maio 2013); "Investigação é atividade de polícia", defende Luís Flávio Gomes, também advogado (Folha de S. Paulo, 23 jun. 2012).

Na mesma data, o artigo de contraponto publicado pela Folha de S. Paulo na seção Tendências e Debates, logo no início das discussões sobre a PEC, demarca a opção retórica dos contrários à PEC: "Quem quer calar o MP?", pergunta João Benedicto de Azevedo Marques, procurador de Justiça aposentado (Folha de S. Paulo, 23 jun. 2012). Para os defensores do poder de investigar do Ministério Público, ainda que eles possam se apoiar em argumentos técnicos, sobre a eficácia dos diferentes modelos de investigação criminal, trata-se de uma discussão política.

Quando se trata das colunas, o número de publicações aumenta e a proporção de textos sem posição assumida também cresce (Gráfico 4). Isso pode se explicar pelo fato de a pesquisa ter adotado a mesma classificação para colunistas como Jânio de Freitas ou Arnaldo Jabor e para colunas de notas, como o Painel, da Folha de S. Paulo, que publicou 
diversos textos não opinativos, mas com informações exclusivas sobre o tema, desde bem cedo, quando a PEC ainda tramitava nas comissões.

Cabe ressaltar ainda que, no âmbito dos estudos sociomidiáticos, os colunistas são considerados definidores primários das questões que serão tematizadas pela imprensa. Definidores primários (Pena, 2006) são atores que atuam diretamente na definição da noticiabilidade e na grandeza dos fatos e interpretações que passarão a ter relevância na esfera da visibilidade pública e suas consequências nas dinâmicas sociais de discutibilidade coletiva (Gomes, 2008). Os colunistas em si já são considerados personagens-paradigma no âmbito do campo jornalístico, uma vez que se trata de personalidades de elevado capital simbólico entre os pares e com reconhecimento público de sua competência, prestígio e status perante os veículos concorrentes e o público. Os colunistas são considerados integrantes da elite jornalística e que também dialogam com as elites políticas e sociais (Kovács, 1979). Além disso, os colunistas elegem os personagens-paradigmas da noticiabilidade e da esfera da opinião jornalística. Por essa razão, a opinião deles assume papel relevante no enquadramento midiático sobre a PEC 37, uma vez que eles atuaram como aliados do MP nas lutas simbólicas e nas controvérsias sobre o tema.

Gráfico 4

Posição das colunas publicadas nos jornais sobre a PEC 37

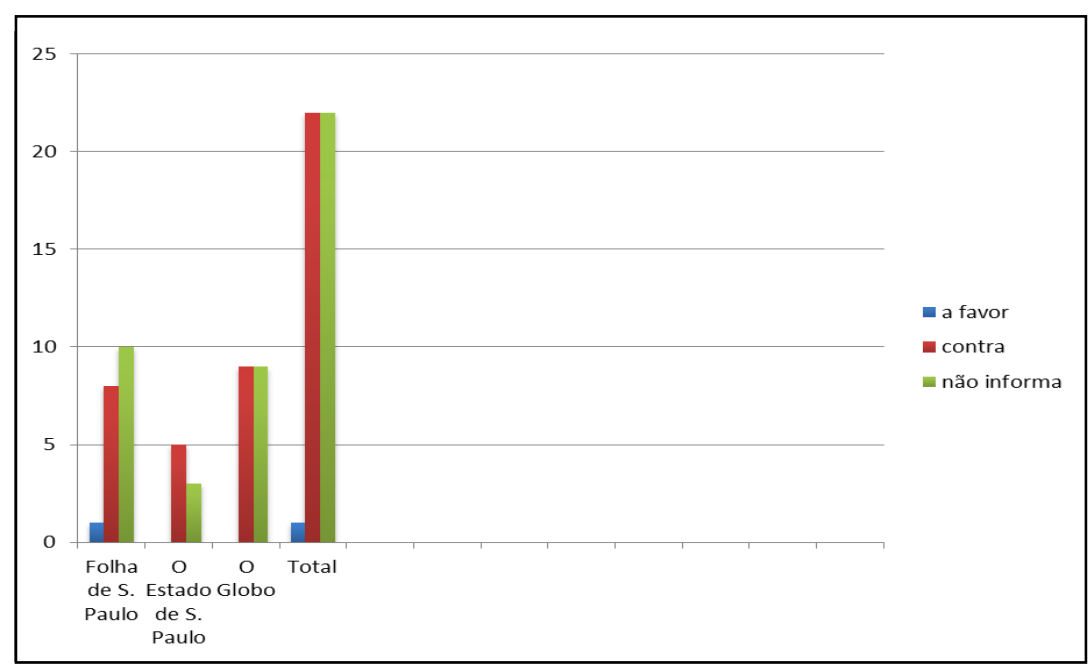

Fonte: Dados da pesquisa.

Já o número de fontes citadas em notícias e reportagens com posição contrária à PEC é maior inclusive no jornal $O$ Estado de S. Paulo (Gráfico 5). Ainda com relação às fontes escolhidas, é interessante observar como os dirigentes de associações que se envolvem no debate, nesse caso, são ao mesmo tempo autoridades - membros do 
LUTAS SIMBÓLICAS NA ARENA MIDIÁTICA: O PODER DE AGÊNCIA DO MINISTÉRIO PÚBLICO E AS CONTROVÉRSIAS SOBRE A PEC 37

Ministério Público, policiais, juízes. Ainda assim, as fontes mais citadas pelos três jornais e pelas quatro revistas analisadas são as do Poder Legislativo (Gráficos 6 e 7).

Gráfico 5

Posição das fontes em notícias e reportagens publicadas em jornais sobre a PEC 37

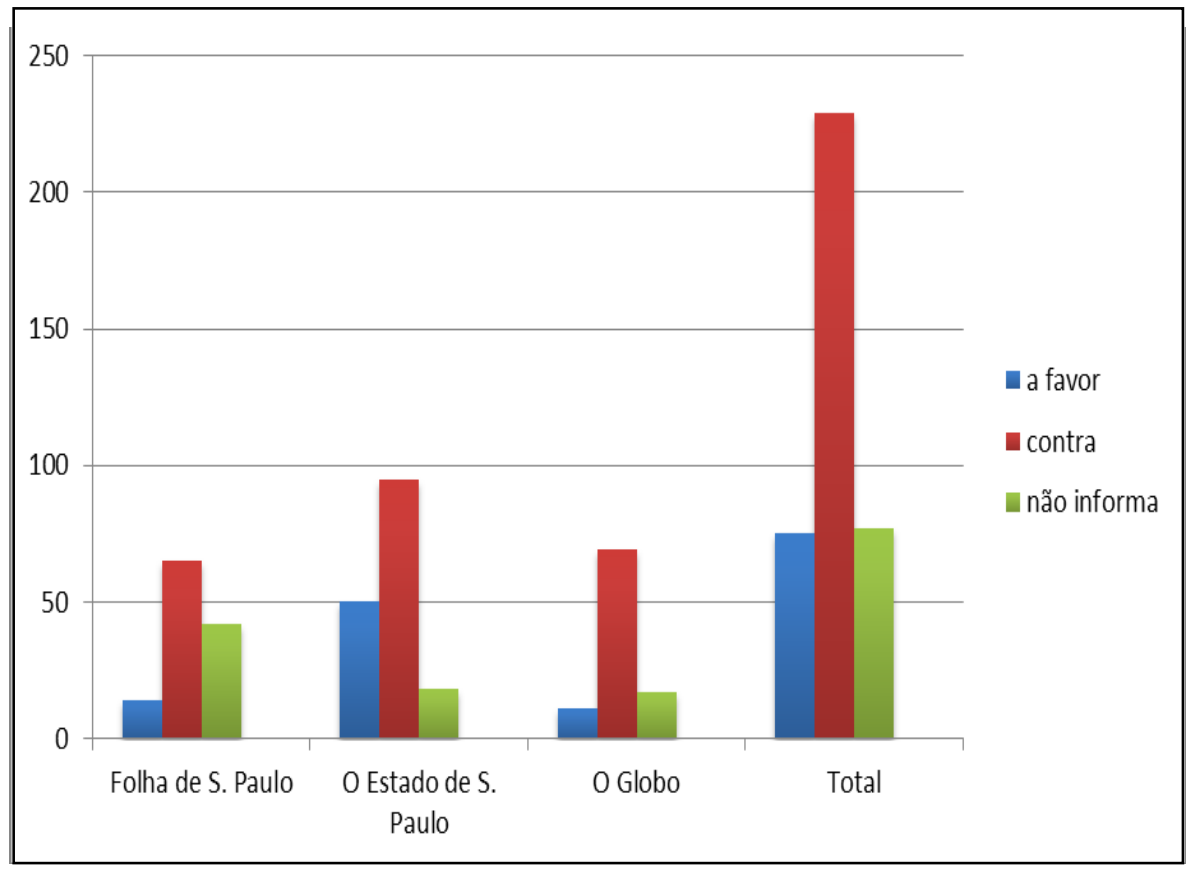

Fonte: Dados da pesquisa. 


\section{Gráfico 6 \\ Origem das fontes citadas em notícias e reportagens publicadas sobre a PEC 37 - jornais}

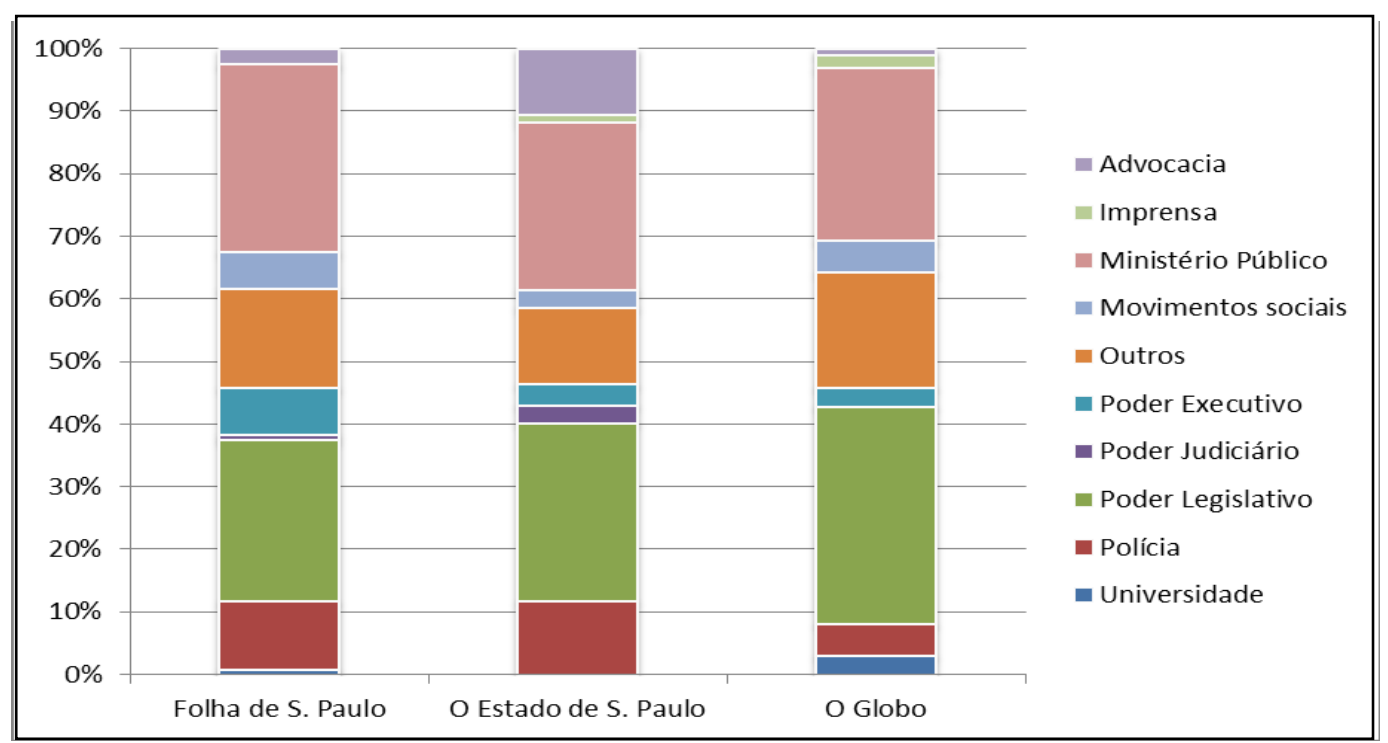

Fonte: Dados da pesquisa

Gráfico 7

Origem das fontes citadas em notícias e reportagens publicadas sobre a PEC 37 - revistas

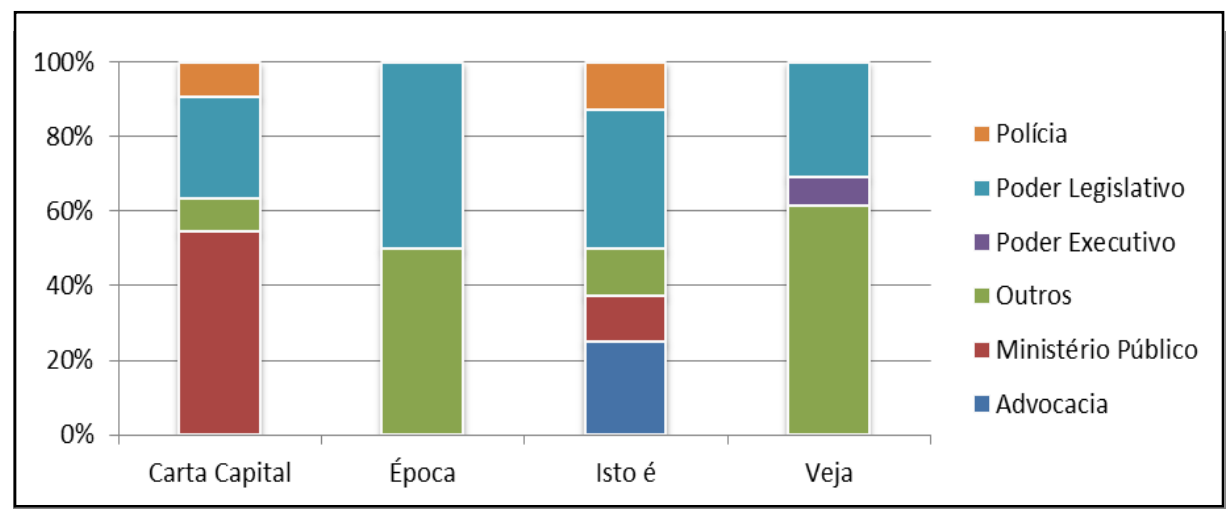

Fonte: Dados da pesquisa.

A fonte mais citada é o presidente da Câmara dos Deputados, Henrique Eduardo Alves. Em segundo lugar, na Folha de S. Paulo e em O Globo, vem o procurador-geral da República, Roberto Gurgel - em O Estado de S. Paulo ele é o terceiro, logo atrás do procurador-geral de Justiça do estado, Márcio Elias Rosa. Na Folha de S. Paulo, o terceiro 
mais citado também é do Ministério Público - Alexandre Camanho, presidente da Associação Nacional dos Procuradores da República. No caso das revistas, as fontes são dispersas, sem predominância, ou não são citadas. A exceção é Carta Capital, que cita duas vezes o autor da PEC, deputado Lourival Mendes, reforçando a predominância de fontes do Poder Legislativo. Aqui, confirmando estudos anteriores, verificamos que:

\begin{abstract}
Uma análise dos atores a quem foi dada visibilidade confirma um achado de outras pesquisas na área da comunicação política: as cotas de visibilidade são distribuídas de forma desigual entre atores políticos e sociais e, principalmente, estão condicionadas às funções que os atores ocupam no centro do poder político (Gomes, 2008, apud Miola, 2011, p. 52).
\end{abstract}

Da mesma forma que as fontes são predominantemente ligadas ao Ministério Público, o enquadramento adotado é aquele conferido pelos defensores da instituição. As matérias citam argumentos como o de que apenas três países no mundo (Uganda, Quênia e Indonésia) proibiam o MP de investigar - dado retirado de uma nota técnica da ANPR e repetido à exaustão nas entrevistas e no material de divulgação produzido pelos procuradores e promotores. Ou têm títulos como "Projeto põe em risco 34 mil investigações" (Folha de S. Paulo, 2 mar. 2013). E, mais importante, adotam o apelido conferido pelo MP à PEC, como em "MP faz atos contra 'PEC da impunidade'" (O Globo, 12 abr. 2013). E aqui não importa a alcunha ser colocada entre aspas, se ela foi reproduzida e os atos públicos contra a proposta noticiados.

A análise dos dados sobre as fontes requer o exame de dois aspectos. O primeiro diz respeito à rede discursiva que é configurada pelos veículos, os quais acionam vozes e perspectivas de julgamento de variados setores sociais, políticos e institucionais. No caso em exame, observa-se como a imprensa acionou e mobilizou argumentos de autoridade e vozes institucionais para compor seus pacotes de informação e de opinião. O segundo reitera a tendência da imprensa de personalização dos debates públicos, com a concentração na visão de determinadas personalidades, seja pela facilidade de acesso e disponibilidade delas para participar do interplay midiático (Wolf, 1995), seja pelo interesse da imprensa na opinião desses personagens-paradigmas (Kovács, 1979) como definidores primários da percepção dos fatos políticos (Pena, 2006). Esse viés da imprensa conduz ao fenômeno denominado de institucionalização por Durão e Coelho (2014), ou seja, a imprensa reduz o olhar dos debates à perspectiva dos representantes e dirigentes de certas instituições.

Também foi analisada a posição das cartas de leitores, majoritariamente contrárias à PEC em todos os jornais (Gráfico 8). Observa-se que elas somente aparecem no início de junho de 2013, um pouco antes das manifestações. Como ressalta Boltanski (2000), em texto no qual analisa as estratégias discursivas dos leitores que enviaram cartas a jornais, tais expedientes tanto servem aos próprios veículos, como aos leitores. Os veículos fazem um uso estratégico dessas cartas (hoje enviadas por e-mail), visto que há uma seleção 
delas, devido à impossibilidade de publicação de todas. Os leitores por sua vez também utilizam manobras retóricas, tanto para sensibilizar os editores, a fim de que sua carta seja escolhida para publicação, quanto no uso de táticas para ressaltar a grandeza moral de seus argumentos. Um exemplo pode ser encontrado numa das primeiras cartas publicadas por O Globo, que critica o argumento favorável à PEC para adotar o ponto de vista da soma de esforços no combate à impunidade, utilizado pelo Ministério Público:

\section{Impunidade}

Muito se tem comentado sobre a PEC 37, e o que poderá ocorrer se for aprovada pelo Congresso. Os que são favoráveis às limitações do Ministério Público "acham" que o MP compromete a isenção e quebra o equilíbrio entre as partes. Se for considerado que a polícia não consegue investigar nem $50 \%$ dos casos, fica evidente que o país precisa de um esforço conjunto de CPIs, Tribunais de Conta, Controladoria Geral da União e corregedorias para que seja proposta a ação penal. No Brasil, onde desmandos acontecem quase diariamente, sem esforço de MP e Polícia Federal, será o caos, ou seja, menos investigação e mais impunidade, o que é preocupante (Edgard Gobbi, Campinas, SP - O Globo, 7 jun. 2013).

No caso da PEC 37, percebe-se um predomínio de opiniões do público contra a aprovação da matéria, mas isso não significa que esse dado seja fiel ao universo de cartas e e-mails efetivamente enviados e recebidos pelos jornais. Visto que passam por um processo de seleção, recorte e montagem, o que é publicado nem sempre é coerente com o universo das opiniões efetivamente manifestadas pelos leitores. Em suma, as cartas dos leitores são usadas estrategicamente pelos jornais a fim de reforçar o apoio da opinião pública nas lutas simbólicas envolvidas nas controvérsias sobre a PEC 37 . Reforça esse argumento o fato de $O$ Globo, que mais claramente se posicionou contra a PEC em editoriais, ser o jornal que publicou maior número de cartas de leitores e, mais importante, todas contrárias à proposta (27, do total de 51$)$.

Vale registrar que das 51 cartas publicadas sobre o tema no período, apenas sete tinham profissão ou cargo de seus autores identificados: dois como presidente da $O A B$, um como presidente de associação do Ministério Público, um como deputado, dois como integrantes do Ministério Público aposentados e um na ativa. Nas outras 44, o autor era identificado apenas pelo nome completo (Folha de S. Paulo) ou pelo nome completo e cidade ( $O$ Estado de S. Paulo e $O$ Globo). E ainda assim é possível perceber pelos argumentos e linguagem uma continuação do embate travado entre as corporações nos demais espaços das mídias e em outras arenas, com os defensores da PEC assumindo a postura de discutir atribuições e seus detratores ocupando a trincheira do ataque à impunidade: 
Ministério Público - Não é por acaso que a propositura da PEC 37 entrou no rol de temas das manifestações lideradas por esses milhares de estudantes e não estudantes que tomaram as ruas. Ora, se é que se pode concluir que o principal foco desses protestos concentra-se no inconformismo com a impunidade e com o desmando na administração da coisa pública, tirar do Ministério Público a possibilidade de investigar, ainda que subsidiariamente, é um retrocesso, pois quem mais sofre com isso é o combate à corrupção e, consequentemente, a cidadania (José Carlos de Oliveira Robaldo, procurador de Justiça aposentado - Campo Grande, MS - Folha de S. Paulo, 21 jun. 2013, Painel do Leitor).

PEC 37 - A respeito do que foi dito pelo procurador aposentado José Carlos de Oliveira Robaldo (21/6), acho oportuno esclarecer que a PEC 37 não retira do Ministério Público qualquer poder, já que, de acordo com o artigo 129 da Constituição, não cabe ao mencionado órgão a investigação de infrações penais. Referidas investigações, de acordo com o artigo 144, competem às polícias. A matéria está definida claramente na Constituição. Ocorre que o Ministério Público vem usurpando a função da polícia. Esse é o objetivo da PEC 37: realçar o que já está na Lei Maior (Vanderley Pimenta - Indaiatuba, SP Folha de S. Paulo, 21 e 23 jun. 2013).

\section{Gráfico 8 \\ Posição das cartas publicadas sobre a PEC 37 (junho de 2013)}

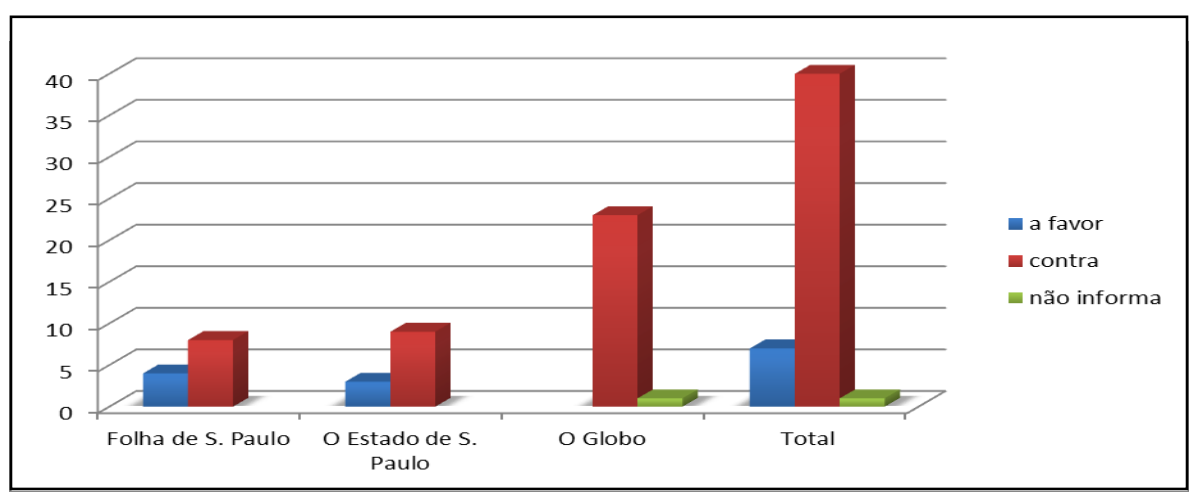

Fonte: Dados da pesquisa.

O número de matérias publicadas em todas as categorias atinge o máximo em junho de 2013, mas já vinha crescendo desde março de 2013 (Gráficos 9 e 10), o que permite concluir que não foram as manifestações que levaram a PEC 37 à imprensa, mas provavelmente o contrário. Pode-se concluir ainda que o ritmo da tramitação da proposta no Congresso e sua repercussão, em razão dos atores interessados na matéria, determinou 
a cobertura feita pela imprensa. Mais uma vez observa-se o engajamento retórico diferenciado do jornal $O$ Globo, o que exigiria uma avaliação qualitativa mais pormenorizada para aprofundar esse dado.

Gráfico 9

Matérias publicadas sobre a PEC 37 em jornais

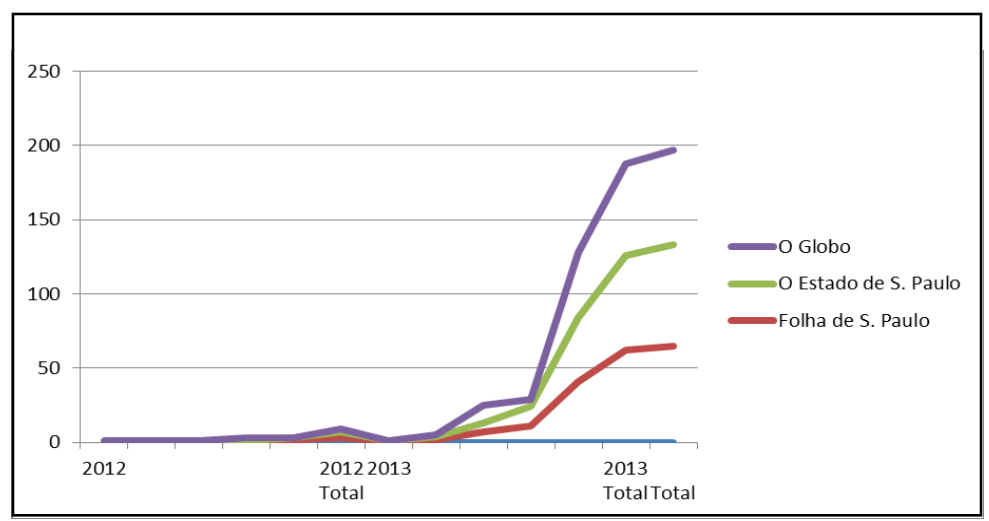

Fonte: Dados da pesquisa.

Gráfico 10

Matérias publicadas sobre a PEC 37 em revistas (2013)

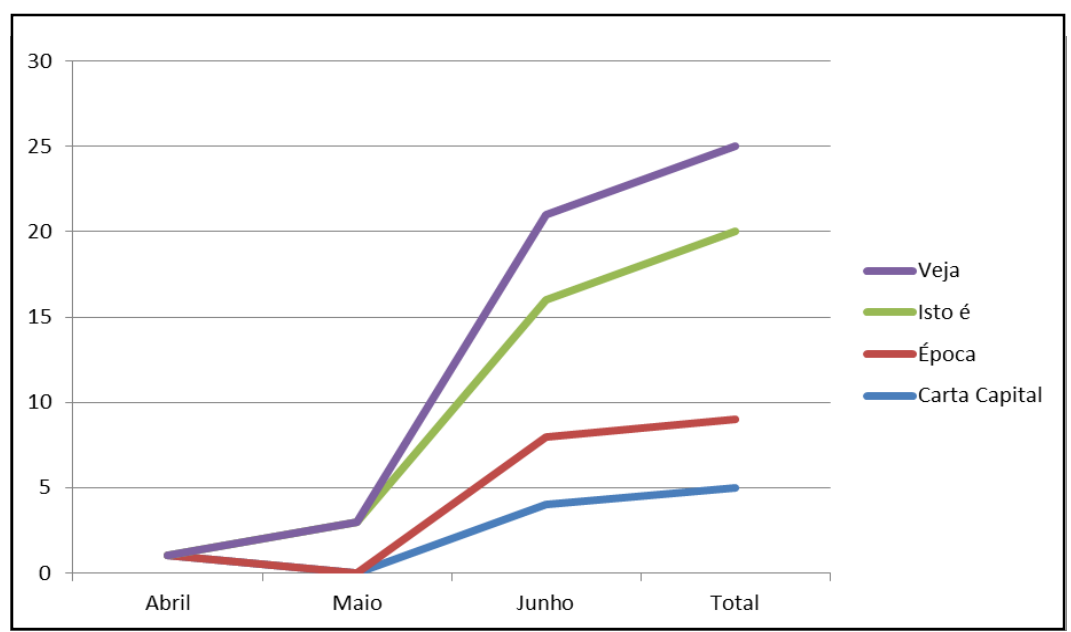

Fonte: Dados da pesquisa.

No que se refere às revistas semanais, a PEC 37 aparece a partir das edições de abril de 2013. A posição das revistas é mais variada que a dos jornais. Em Época, neutros e contrários se equilibram, sem fontes favoráveis à PEC, enquanto na IstoÉ as fontes 
favoráveis predominam. Em Veja e Carta Capital, por outro lado, predominam fontes contrárias à PEC (Gráfico 11).

\section{Gráfico 11 \\ Posição das fontes de matérias publicadas sobre a \\ PEC 37 em revistas}

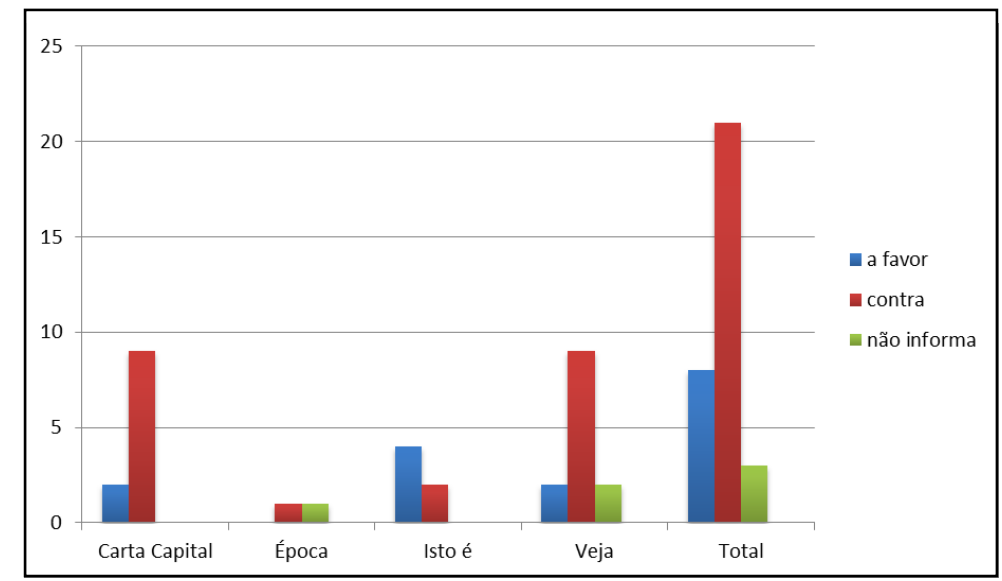

Fonte: Dados da pesquisa.

Quanto à performance das revistas semanais, cabe destacar alguns dos diferenciais do jornalismo de revista (Tavares e Schwaab, 2013), a começar pela periodicidade semanal e o estilo de texto, uma vez que os jornais fazem quase uma espécie de prontuário do registro temporal dos acontecimentos (Bergamo, 2011), enquanto as revistas publicam um balanço semanal, geralmente com enfoque mais interpretativo e analítico. Uma análise comparativa das lógicas de cobertura sobre a PEC 37 pelos jornais e revistas também exigiria um esforço de aprofundamento que extrapola os limites de um artigo com uma perspectiva exploratória, como o que ora apresentamos.

\section{Conclusões}

Como vimos ao longo do texto, a pesquisa mostra como a arena midiática é relevante nos estudos sobre as lutas simbólicas e como a imprensa pode potencializar o poder de agência de determinados atores, como ocorreu no caso das controvérsias sobre a PEC 37, em que a imprensa aderiu ao ponto de vista do Ministério Público. Com isso, a perspectiva argumentativa do MP adquiriu ampla visibilidade e projeção, favorecendo a adesão dos grupos que protagonizaram as manifestações de junho de 2013. O resultado, como já foi demonstrado, foi a rejeição da PEC pela Câmara dos Deputados, em um cenário político em que, antes do ativismo midiático e da intensidade das manifestações, a 
aprovação da matéria era dada como certa. A atuação da imprensa e a adesão dos manifestantes fortaleceu o enquadramento que enfatizava a conexão entre corrupção e política no debate sobre a PEC 37, sintoma da importância adquirida pelo tema no momento político brasileiro e, a rigor, na história política do país.

Constatou-se, na pesquisa, que o enquadramento conferido pelo Ministério Público, ao adotar o slogan "PEC da impunidade", prevaleceu nos debates. A despeito das tentativas de contra-argumentação feitas pelos delegados de polícia e por parlamentares, a apresentação da PEC 37 como artifício para proteger corruptos foi acolhida pela imprensa e pela opinião pública, abrindo caminho para incluir a derrubada da PEC entre as reivindicações das manifestações de junho. Um exemplo da prevalência desse enquadramento é a referência à PEC no posfácio da edição brasileira do livro de Castells sobre movimentos sociais na internet:

Um Congresso grotesco, com burocratas partidários e chefetes locais corruptos que por vezes resolvem suas diferenças a tiros de pistola. Um Congresso que havia proposto um decreto (uma Proposta de Emenda à Constituição, PEC) para tirar do Ministério Público o direito de investigar a corrupção, e que, ante a pressão das ruas, se apressou a votar contra seu próprio projeto, quase por unanimidade. Obviamente esperando fazer o mesmo por outras vias, quando as coisas se acalmarem (Castells, 2013, p. 185).

O levantamento feito junto aos órgãos e associações do MP verificou que houve atuação extensa e intencional para evitar a aprovação da PEC. A totalidade dos órgãos que responderam ao questionário se envolveu na campanha realizada em conjunto com as associações do MP, numa parceria entre instituições de Estado e organizações corporativas que merece registro e levanta indagações. De início, seria relevante comparar a mobilização das associações e dos órgãos do MP com o envolvimento dos policiais e das polícias.

Há outras indagações trazidas pela pesquisa que merecem aprofundamento. Citamse aqui algumas delas. No que se refere à mídia, a cobertura sobre a PEC 37 realizada pelas televisões certamente é de grande interesse para a análise que foi desenvolvida, tendo em vista o grande alcance desse meio. Seria ainda relevante verificar se a imprensa regional deu à $\mathrm{PEC}$ tratamento similar àquele conferido pela imprensa nacional, uma vez que o trabalho dos integrantes do MP foi intenso também nos estados. Além disso, entre os estudos que já abordaram o papel das mídias sociais nos eventos de junho de 2013, ainda não se identificou algum que tivesse tratado especificamente da PEC 37.

Por outro lado, é provável que os estudiosos interessados na evolução do Ministério Público no Brasil se detenham no caso da PEC 37, tanto pelo que representa de inédito quanto pelo que mostra de continuidade na história da instituição. Arantes $(2000,2013)$ demonstrou que coube aos membros do MP a iniciativa na reformulação da proposta e encaminhamento à instituição pelo Poder Legislativo, nas décadas de 1980 e 1990, e 
também indicou como nos últimos 20 anos esse arranjo estava se alterando, com outras corporações assumindo posições de destaque no debate legislativo, entre elas os policiais. No debate sobre a PEC 37, o Ministério Público virou o jogo, dado como ganho pelos policiais, numa disputa corporativa que é, em si, tema de interesse.

A relação do MP com o parlamento - agindo como grupo de interesse em defesa de suas prerrogativas ou sendo ouvido a respeito de investigações ou fiscalizações -, com os políticos e com a política, quando atua, é outro ponto que tem merecido atenção. Para além do ativismo judicial, os críticos se referem à judicialização da política, num movimento em que o Ministério Público e o Poder Judiciário estariam assumindo um lugar que cabe aos políticos, com grave prejuízo para a democracia (Aragão, 2012; Moreira, 2012, 2013).

Por fim, ainda que as ações de comunicação do Ministério Público tenham sido objeto deste artigo, no caso específico da PEC 37, os dados obtidos indicam que o tema merece maior reflexão. Verifica-se que o Ministério Público tem ampliado a importância dada à comunicação, tanto no que se pode considerar um movimento de profissionalização comum a outras instituições, quanto como consequência de uma concepção específica de sua atuação (Barenboïm, 2014). Ao utilizar estratégias adequadas de comunicação, o MP aumenta seu potencial de repercussão na arena midiática e fortalece seu papel de ator nas lutas simbólicas, ao ser reconhecido pela imprensa como uma fonte perita e credível. Além disso, como vimos anteriormente, a própria função de investigar crimes de corrupção favorece a simpatia da imprensa pelo trabalho do MP. O ato de denunciar, seja do MP, seja da imprensa, adquire relevância como objeto de estudo para os analistas sociais e políticos, devido ao regime de ação que orienta esse tipo de agenciamento moral, motivado por ideais de justiça e de expectativas de progresso moral, com a punição dos agentes da corrupção (Boltanski e Thévenot, 1991).

No caso em exame, as lutas simbólicas penderam para a atuação do MP, devido ao apoio e ativismo da mídia, que contribuiu para transformar o tema em uma causa pública de amplo apelo moral, devido à associação que o MP empreendeu ao cunhar a proposta de "PEC da impunidade". Como o combate à corrupção é uma causa que encontra ampla ressonância na opinião pública, o tema adquiriu grande capilarização no debate público, com o agenciamento midiático, devido à inserção de uma pluralidade de vozes favoráveis à visão do MP nessa arena discursiva, com editoriais, artigos de opinião, entrevistas, opinião de colunistas, juristas e especialistas, além da divulgação de cartas de leitores. Isso ampliou a inserção social do tema, com a inclusão do enquadramento do Ministério Público nas redes sociais digitais e o acolhimento da campanha pela rejeição da PEC 37 pelos principais grupos que protagonizaram as manifestações de junho de 2013.

Além disso, parece correto dizer que, entre as diversas demandas transformadas em bandeiras naquele junho de 2013, governo e parlamentares-alvo das manifestações buscaram atender às que eram identificadas com reivindicações específicas. Assim, os 
aumentos de passagens de ônibus em São Paulo e outras cidades foram revogados e a PEC 37 foi colocada em votação e derrubada em junho mesmo. Logo depois, em agosto, a destinação dos royalties do petróleo do pré-sal para a educação e saúde foi aprovada pelo Congresso e sancionada pela presidente da República ${ }^{20}$.

Por todas essas razões, a Câmara dos Deputados mudou sua posição nas lutas simbólicas, ao rejeitar a proposta, mesmo contrariando os interesses de segmentos expressivos do Poder Legislativo, insatisfeitos com recomendações e investigações do MP que afetam os próprios deputados e senadores. Em uma postura de realinhamento ao clima de opinião que se tornou hegemônico, os parlamentares adotaram um novo regime de ação, ao abandonarem a lógica da grandeza doméstica (ancorada em interesses pessoais) e adotarem uma postura realinhada com princípios da grandeza cívica (fundamentada em interesses coletivos) -, sob pressão popular e midiática. Afinal, aprovar uma proposta cujo teor fora reconhecido por múltiplos atores sociais e políticos e pela própria opinião pública como "PEC da impunidade" resultaria em grande prejuízo para a reputação pública do parlamento, cuja imagem já é negativa perante a sociedade. Embora isso não signifique uma mudança substantiva na postura dos parlamentares, é emblemático do ponto de vista específico do caso em exame, apontando para as teorias utilizadas para fundamentar a análise, as quais reforçam a plasticidade da ação social, a força política das controvérsias e a influência da arena midiática que pode favorecer ou desfavorecer a performance de determinados atores, no dinamismo do interplay midiático envolvido nas lutas simbólicas da atualidade.

Cláudia Regina Fonseca Lemos - Doutora em Estudos Literários pela UFMG. Docente e pesquisadora do Programa de Pós-Graduação do Centro de Formação da Câmara dos Deputados (CEFOR). E-mail: <claudiarflemos@gmail.com>.

Antonio Teixeira de Barros - Doutor em Sociologia. Docente e pesquisador do Programa de Pós-Graduação do Centro de Formação da Câmara dos Deputados. Email: <antonibarros@gmail.com>.

\section{Referências bibliográficas}

ARAgÃo, E. J. G. "O Ministério Público na encruzilhada: parceiro entre sociedade e Estado ou adversário implacável da governabilidade?" In: LuCCA, N. Homenagem ao professor Michel Temer. São Paulo: Quartier Latin, 2012. Disponível em: <http://congressoemfoco.uol.com.br/noticias/o-ministeriopublico-na-encruzilhada-\%E2\%80\%93-1\%C2\%AA-parte/>. Acesso em: 29 mar. 2015.

Arantes, R. B. "Ministério Público e política no Brasil". Faculdade de Filosofia, Letras e Ciências

\footnotetext{
${ }^{20}$ Presidente sanciona sem vetos projeto que destina royalties do petróleo para educação e saúde. Disponível em: <http://www2.camara.leg.br/camaranoticias/noticias/EDUCACAO-E-CULTURA/451500-PRESIDENTESANCIONA-SEM-VETOS-PROJETO-QUE-DESTINA-ROYALTIES-DO-PETROLEO-PARA-EDUCACAO-ESAUDE.html>. Acesso em: 27 nov. 2015.
} 
Humanas, Universidade de São Paulo. Tese de Doutorado. Departamento de Ciência Política. São Paulo, USP, 2000.

ARANTES, R. B. "PEC 37: o que as ruas não perceberam". Le Monde Diplomatique Brasil, nov. 2013. Disponível em: <http://www.diplomatique.org.br/artigo.php?id=1534>. Acesso em: 13 nov. 2013.

BARENBOÏM, D. "Por uma nova causa de legitimação para o Ministério Público". Le Monde Diplomatique Brasil, dez. 2014. Disponível em:

<http://www.diplomatique.org.br/acervo.php?id=3090\&tipo=acervo>. Acesso em: 9 fev. 2015.

BARros, A. T. "Editoriais jornalísticos sobre ecologia: opinião privada como opinião publicamente mediada". Comunicação \& Informação, Goiânia, vol. 3, no 1, p. 65-79, jan./jun. 2000.

Bergamo, A. "Reportagem, memória e história no jornalismo brasileiro". Mana, Rio de Janeiro, vol. 17, no 2, ago., p. 233-269, 2011.

Bernardes, C. B.; Barros, A. T. "A credibilidade jornalística como instrumento para ampliação da confiança no parlamento". In: MessenberG, D., et al. Estudos legislativos: 20 anos da Constituição brasileira. Brasília: Senado Federal/Câmara dos Deputados/Tribunal de Contas da União/Universidade de Brasília, p. 164-192, 2010.

BIRoli, F. "Técnicas de poder, disciplinas do olhar: aspectos da construção do jornalismo moderno no Brasil". História, São Paulo, vol. 26, no 2, p. 118-143, 2007.

Biroli, F.; MANTOVAni, D. "A parte que me cabe nesse julgamento: a Folha de S. Paulo na cobertura ao processo do mensalão". Opinião Pública. Campinas, vol. 20, no 2, p. 205-218, ago. 2014.

Biroli, F.; Miguel, L. F. "Meios de comunicação, voto e conflito político no Brasil". Revista Brasileira de Ciências Sociais. São Paulo, vol. 28, no 81, p. 77-96, fev. 2013.

BolTANSKI, L. L'amour et la justice comme compétences: trois essais de sociologie de l'action. Paris: Métailié, 1990. . El amor y la justicia como competencias. Buenos Aires: Amorrotu, 2000.

BoltAnSki, L.; TheVenot, L. De la justification: les économies de la grandeur. Paris: Gallimard, 1991.

Botelho, J. S.; MAiA, R. C. M.; Mundim, P. S. "O debate em torno das cotas nas universidades públicas brasileiras de 2001 a 2009: uma análise preliminar". Revista Compolítica, vol. 1, n 2, set-out. 2011.

BouRdieu, P. O poder simbólico. Rio de Janeiro: Bertrand Brasil, 1989. . Razões práticas. Oeiras: Celta Editora, 1997.

BuccI, E. O Estado de Narciso. A comunicação pública a serviço da vaidade particular. São Paulo: Companhia das Letras, 2015.

CASTELLS, M. Redes de indignação e esperança: movimentos sociais na era da internet. Rio de Janeiro: Zahar, 2013.

ConAmp. Associação Nacional dos Membros do Ministério Público. Relatório de Gestão Conamp 20122014. Brasília: Conamp, 2014.

Conselho nacional do Ministério Público. Nota técnica do Conselho Nacional do Ministério Público sobre a Proposta de Emenda à Constituição no 37, de 2011. Brasília: CNMP, 29 maio 2012. Disponível em: <http://www.cnmp.mp.br/portal/images/stories/Normas/notastecnicas/nota_tecncia_CNMP__poderes_investigatorios.pdf >. Acesso em: 21 mar. 2015.

DuARTE, J. Comunicação pública: Estado, mercado, sociedade e interesse público. São Paulo: Atlas, 
2007.

DurÃo, S.; CoElho, M. C. "Morais do drama urbano: violência policial, discurso midiático e produção de contos morais". Sociedade e Estado, Brasília, vol. 29, no 3, p. 921-940, dez. 2014.

Elmelund-Praestekaer, C.; Wien, C. "What's the fuss about? The interplay of media hypes and politics". The International Journal of Press, vol. 13, no 3, p.247-266, 2008.

ENTMAN, R. M. "Framing bias: media in the distribution of power". Journal of Communication, vol. 57, n० 1 , p. $163-173,2007$.

EtTema, J. S.; Glasser,T. L. Custodians of conscience: investigative journalism and public virtue. Columbia: Columbia University Press, 1998.

Giddens, A. A constituição da sociedade. São Paulo: Martins Fontes, 2003.

Giumbelli, E. "Para além do 'trabalho de campo': reflexões supostamente malinowskianas". Revista Brasileira de Ciências Sociais, vol. 17, no 48, p. 91-107. 2002.

Gomes, W. "Capital social, democracia e televisão em Robert Putnam". In: GomeS, W.; MAIA, R. C. M. (orgs.). Comunicação e democracia: problemas e perspectivas. São Paulo: Paulus, p. 221-273, 2008.

KovÁcs, A. "Coluna social: linguagem e montagem". Comum, Rio de Janeiro, vol. 2, no 5, p. 38-90, jan.-mar. 1979.

KRIEger, M. G. "Editoriais jornalísticos: discursos de representação do interesse coletivo". Revista de Comunicação e Biblioteconomia. Porto Alegre, no 5, p. 158-164, dez. 1990.

LANÇA, I. B. A configuração dos acontecimentos públicos. Coimbra: Minerva, 2006.

MAIA, R. Em busca do interesse público: tensões entre a argumentação e a barganha. In: KUNSCH, M. (org.). Comunicação pública, sociedade e cidadania. São Caetano do Sul: Difusão, 2011.

MAIA, R., et al. A teoria crítica nos estudos da Comunicação: uma agenda empírica para o programa de Jürgen Habermas e de Axel Honneth. In: FRANÇA, V. V. (org.). Teorias da comunicação no Brasil: reflexões contemporâneas. Salvador/Brasília: Edufba/Compós, 2014.

MARICATO, E., et al. Cidades rebeldes: passe livre a as manifestações que tomaram as ruas do Brasil. São Paulo: Boitempo/Carta Maior, 2013.

MiOLA, E. "Representações do jornalismo sobre a radiodifusão pública: o debate em torno da criação da Empresa Brasil de Comunicação na imprensa". Revista Compolítica. Rio de Janeiro, , vol. 2, no 2, set.out. 2011.

MoReIRA, L. "Judicialização da política no Brasil". Le Monde Diplomatique Brasil, fev. 2013. Disponível em: <http://www.diplomatique.org.br/artigo.php?id=1364>. Acesso em: 29 mar. 2015.

(org.). Judicialização da política. São Paulo: 2Editorial, 2012.

NASCIMENTO, S. "Jornalismo sobre investigações: relações entre Ministério Público e a imprensa". Tese de Doutorado em Comunicação. Universidade de Brasília, Brasília, 2007. Disponível em: <http://repositorio.unb.br/handle/10482/6557>. Acesso em: 29 mar. 2015.

PENA, F. Teorias do jornalismo. São Paulo: Contexto, 2006.

PINTO, C. R. J. "O conceito de reconhecimento e os desafios da teoria democrática contemporânea ou $\mathrm{O}$ que as teorias do reconhecimento têm a dizer sobre manifestações de rua no Brasil em 2013". Anais do $38^{\circ}$ Encontro Anual da Anpocs, de 27 a 31 out. 2014, Caxambu-MG. 
LUTAS SIMBÓLICAS NA ARENA MIDIÁTICA: O PODER DE AGÊNCIA DO MINISTÉRIO PÚBLICO E AS CONTROVÉRSIAS SOBRE A PEC 37

Silva, R. H. A. Ruas e redes: dinâmicas dos protestosBR. Belo Horizonte: Autêntica, 2014.

Silva, T. "Comunicação e mobilização: o movimento 'Não Foi Acidente' e a campanha em torno de um problema público no Brasil". Revista Brasileira de Ciências da Comunicação. São Paulo, vol.37, no 2, p. 113-132, jul./dez. 2014. Disponível em:

<http://www.portcom.intercom.org.br/revistas/index.php/revistaintercom/article/view/2112/1820>. Acesso em: 8 fev. 2015.

TAVARes, F. M. B.; SchwaAB, R. A revista e seu jornalismo. Porto Alegre: Penso, 2013.

Wolf, M. Teorias da comunicação. São Paulo: Martins Fontes, 1995.

UnANUA, F. J. T. "Infraestructuras, industria y movimientos sociales. Estrategias de comunicación ante el proyecto de Refinería Balboa en la Provincia de Badajoz". Revista de Comunicación y Ciudadania Digital, vol. 3, no 2, Diciembre 2014. Disponível em:

<http://reuredc.uca.es/index.php/cayp/article/viewFile/682/653>. Acesso em: 4 fev. 2015

\title{
Resumo
}

Lutas simbólicas na arena midiática: o poder de agência do Ministério Público e as controvérsias sobre a PEC 37

O artigo analisa, com base em referencial sociológico, as lutas simbólicas na arena midiática acerca das controvérsias relacionadas à Proposta de Emenda Constitucional que proibia o Ministério Público (MP) de conduzir investigações criminais, a chamada PEC 37. O objetivo é compreender como os diversos atores interessados no assunto travaram o debate, levando o tema a chegar às manifestações de junho de 2013. O material empírico analisado inclui 351 textos jornalísticos, entrevistas e questionários com os representantes do MP dos estados e da União, além do Conselho Nacional do Ministério Público e das associações da categoria. As principais conclusões indicam que prevaleceu na imprensa o enquadramento conferido pelo MP, ao adotar o slogan "PEC da impunidade". A despeito da contra-argumentação de delegados de polícia e parlamentares, a visão do MP foi acolhida pela imprensa e pela opinião pública, abrindo caminho para incluir a derrubada da PEC entre as reivindicações das manifestações de junho de 2013.

Palavras-chave: sociologia política; discurso midiático; controvérsias políticas; Ministério Público; PEC 37

\begin{abstract}
Symbolic fights in the media arena: the power of agency of Brazilian public prosecution services and the controversies about PEC 37, the "Impunity Bill"

This article adopts a sociological perspective to analyze the symbolic fights in the media surrounding controversies related to the "PEC 37" constitutional amendment, which prohibits the Ministério Público (Public Prosecution Office) from directly conducting criminal investigations. The present work aims to understand how the different actors interested in the subject led the debate on the bill, bringing the matter to the demonstrations that emerged in Brazil in June 2013. The empirical data analyzed include 351 newspaper articles, questionnaires and interviews with members of the Public Prosecution Office at both the national and state levels, as well as with members of the Conselho Nacional do Ministério Público and its unions. The main conclusions indicate that the Public Prosecution's framing of the socalled "Impunity Bill" prevailed in the press. Despite the counter-arguments of police chiefs and congressional representatives, both the press and public opinion adopted the Prosecution's point of
\end{abstract}


view, leading to the rejection of the bill in Congress, after protesters in June 2013 included it among their grievances.

Keywords: Political Sociology. Media discourse. Political controversies. Public Prosecution Office. PEC37

\section{Resumen}

Combate simbólico en el campo de los medios: el poder de agencia del Ministerio Público y las controversias sobre la PEC 37, el proyecto de "Ley de Impunidad"

Este artículo analiza las disputas simbólicas en el campo de los medios acerca de las controversias relacionadas con la Propuesta de Enmienda Constitucional (PEC 37) que prohibía al Ministerio Público (MP) de llevar a cabo investigaciones criminales. El objetivo es comprender cómo los diversos actores interesados en el tema condujeron el debate, llevando el tema a las manifestaciones de junio de 2013. Los datos empíricos analizados incluyen 351 artículos de periódicos, entrevistas y cuestionarios con representantes del Ministerio Público de los estados y de la Unión, además de las asociaciones de los fiscales. Los principales resultados indican que prevaleció en la prensa el marco propuesto por el Ministerio Público, adoptando el lema "PEC de la impunidad". A pesar de los argumentos en contra de los jefes de policía y de miembros del Parlamento, la opinión del MP fue bien recibida por la prensa y la opinión pública, allanando el camino para incluir el derrocamiento de la PEC entre las reivindicaciones de las manifestaciones de junio de 2013.

Palabras clave: sociología política; discurso de los medios; disputas simbólicas; Ministerio Público; PEC 37

\section{Résumé}

Combat symbolique dans l'arène des médias : la puissance d'agir du Ministère Publique et les controverses sur le PEC 37, le projet de "Loi de I'Impunité"

Cet article, fondé sur un référentiel sociologique, analyse les luttes symboliques dans les médias à propos de la controverse liée au Projet d'amendement de la Constitution brésilienne (PEC 37) qui restreignait la possibilité d'enquête criminelle par le Ministère Public. L'objectif est de comprendre comment les acteurs intéressés ont conduit le débat et ont inclut le sujet dans les manifestations de Juin 2013. Les données empiriques analysées comprennent 351 articles de journaux et de magazines, des interviews et des questionnaires auprès de représentants du Ministère public des états et de I'Union, outre le Conseil national du Ministère public et de ses associations. Les principaux résultats indiquent qu'a prévalu dans la presse le cadre construit par les procureurs, en adoptant le slogan "PEC de I'impunité". Malgré les contre-arguments des chefs de police et des députés, le point de vue du Ministère public a été bien accueilli par la presse et I'opinion publique, ouvrant la voie à I'inclusion du renversement du PEC parmi les revendications des manifestations de Juin 2013.

Mots-clés: sociologie politique; discours des médias; luttes symboliques; Ministère Public; PEC

Artigo submetido à publicação em dezembro de 2015.

Versão final aprovada em outubro de 2016. 